US Army Corps of Engineers

Prepared for the U.S. Army Corps of Engineers, Portland District, Under a Government Order with the U.S. Department of Energy

Contract DE-AC05-76RL01830

\title{
Compliance Monitoring of Juvenile Subyearling Chinook Salmon Survival and Passage at The Dalles Dam, Summer 2010
}

\author{
GE Johnson \\ TJ Carlson \\ JR Skalski
}

Prepared by:

Pacific Northwest National Laboratory

University of Washington

December 2010

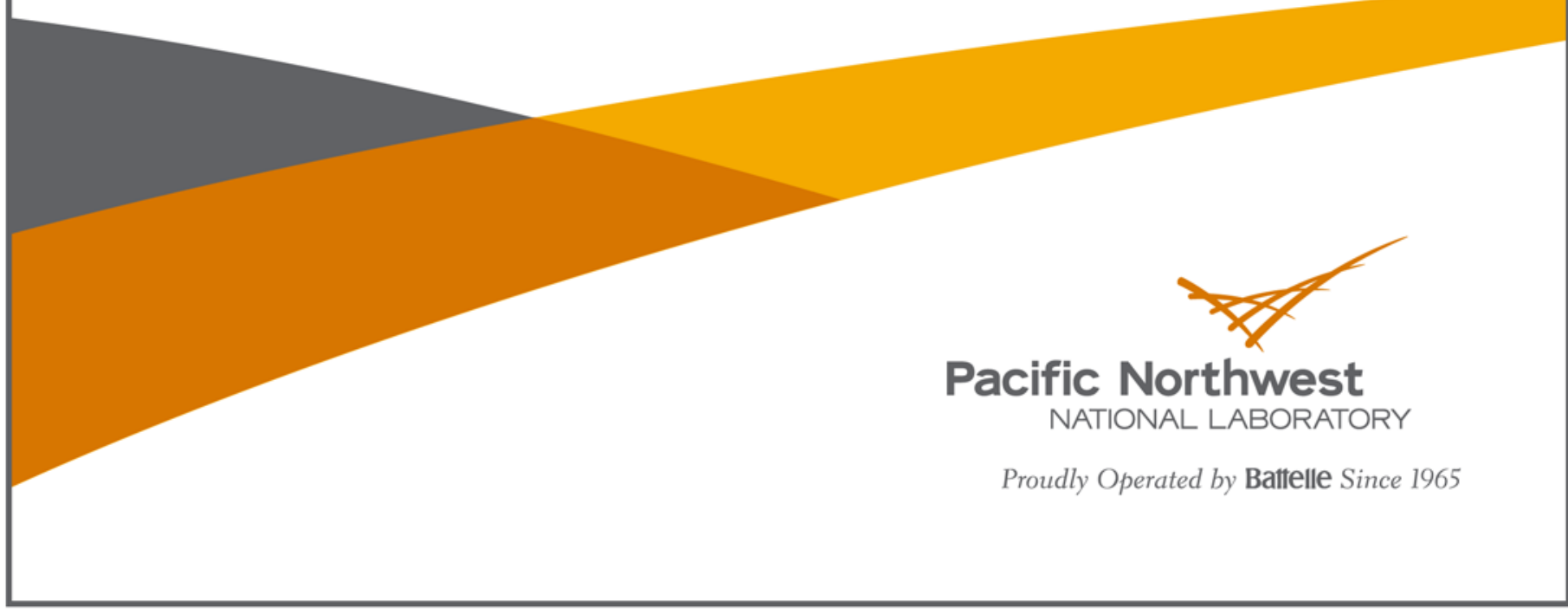




\title{
DISCLAIMER
}

This report was prepared as an account of work sponsored by an agency of the United States Government. Neither the United States Government nor any agency thereof, nor Battelle Memorial Institute, nor any of their employees, makes any warranty, express or implied, or assumes any legal liability or responsibility for the accuracy, completeness, or usefulness of any information, apparatus, product, or process disclosed, or represents that its use would not infringe privately owned rights. Reference herein to any specific commercial product, process, or service by trade name, trademark, manufacturer, or otherwise does not necessarily constitute or imply its endorsement, recommendation, or favoring by the United States Government or any agency thereof, or Battelle Memorial Institute. The views and opinions of authors expressed herein do not necessarily state or reflect those of the United States Government or any agency thereof.

\author{
PACIFIC NORTHWEST NATIONAL LABORATORY \\ operated by \\ BATTELLE \\ for the \\ UNITED STATES DEPARTMENT OF ENERGY \\ under Contract DE-AC05-76RL01830
}

Printed in the United States of America
Available to DOE and DOE contractors from the
Office of Scientific and Technical Information,
P.O. Box 62, Oak Ridge, TN 37831-0062;
ph: (865) 576-8401
fax: $(865)$ 576-5728
email: reports@adonis.osti.gov

Available to the public from the National Technical Information Service

5301 Shawnee Rd., Alexandria, VA 22312

ph: (800) 553-NTIS (6847)

email: orders@ntis.gov $<$ http://www.ntis.gov/about/form.aspx $>$

Online ordering: http://www.ntis.gov

This document was printed on recycled paper. 


\title{
Compliance Monitoring of Juvenile Subyearling Chinook Salmon Survival and Passage at The Dalles Dam, Summer 2010
}

\author{
GE Johnson \\ TJ Carlson \\ JR Skalski*
}

December 2010

Prepared for

U.S. Army Corps of Engineers, Portland District

Under a Government Order with the U.S. Department of Energy

Contract DE-AC05-76RLO 1830

Pacific Northwest National Laboratory

Richland, Washington 99352

* University of Washington, Seattle, Washington
Pacific Northwest National Laboratory, Richland, Washington 



\section{Preface}

This study was conducted by the Pacific Northwest National Laboratory (PNNL) and the University of Washington (UW) for the U.S. Army Corps of Engineers, Portland District (USACE). The PNNL and UW project managers are Drs. Thomas J. Carlson and John R. Skalski, respectively. The USACE technical lead is Mr. Brad Eppard. The study was designed to estimate dam passage survival at The Dalles Dam as stipulated by the 2008 Federal Columbia River Power System Biological Opinion and provide additional performance measures at that site as stipulated in the Columbia Basin Fish Accords.

This summary report focuses on the summer run of subyearling Chinook salmon. A separate summary report delivered in October 2010 presented the findings of the yearling Chinook salmon and steelhead survival studies at The Dalles Dam during spring 2010. Comprehensive technical reports of the 2010 tagging studies at John Day, The Dalles, and Bonneville dams, including fish survival, behavior, and passage results, will be delivered in 2011. 



\section{Executive Summary}

The purpose of this compliance study was to estimate dam passage survival of subyearling Chinook salmon smolts at The Dalles Dam during summer 2010. Under the 2008 Federal Columbia River Power System (FCRPS) Biological Opinion (BiOp), dam passage survival should be greater than or equal to 0.93 and estimated with a standard error (SE) less than or equal 0.015 . The study also estimated smolt passage survival from the forebay 2 river kilometers ( $\mathrm{rkm}$ ) upstream of the dam to the tailrace $2 \mathrm{rkm}$ below the dam ${ }^{1}$, forebay residence time, tailrace egress time, and fish passage efficiency, as required in the Columbia Basin Fish Accords, as well as spill passage efficiency.

A virtual/paired-release design was used to estimate dam passage survival at The Dalles Dam. The approach included releases of acoustic-tagged smolts above John Day Dam that contributed to the formation of a virtual release at the face of The Dalles Dam. A survival estimate from this release was adjusted by a paired release below The Dalles Dam. A total of 4,449 subyearling Chinook salmon smolts were tagged and released in the study. The Juvenile Salmon Acoustic Telemetry System (JSATS) tag model number ATS-156dB, weighing $0.430 \mathrm{~g}$ in air, was used in this investigation.

The study results are summarized in the following tables.

Table ES.1. Estimates of Dam Passage Survival ${ }^{2}$ at The Dalles Dam in 2010

\begin{tabular}{ccc}
\hline Project & Year & Subyearling Chinook Salmon \\
\hline The Dalles Dam & 2010 & $0.9404(\widehat{\mathrm{SE}}=0.0091)$ \\
\hline
\end{tabular}

Table ES.2. Fish Accords Performance Measures at The Dalles Dam in 2010

\begin{tabular}{ll}
\hline \multicolumn{1}{c}{ Performance Measures } & Subyearling Chinook Salmon \\
\hline Forebay-to-tailrace survival & $0.9356(\widehat{\mathrm{SE}}=0.0092)$ \\
Forebay residence time (mean) & $0.72 \mathrm{~h}(\widehat{\mathrm{SE}}=0.28)$ \\
Tailrace egress time (mean) & $1.42 \mathrm{~h}(\widehat{\mathrm{SE}}=0.28)$ \\
Spill passage efficiency & $0.7122(\widehat{\mathrm{SE}}=0.0092)$ \\
Fish passage efficiency & $0.8298(\widehat{\mathrm{SE}}=0.0076)$ \\
\hline
\end{tabular}

${ }^{1}$ The forebay-to-tailrace survival estimate satisfies the "BRZ-to-BRZ" survival estimate called for in the Fish Accords.

${ }^{2}$ Dam passage survival is defined as survival from the upstream face of the dam to a standardized reference point in the tailrace.

${ }^{3}$ Spill passage efficiency presented here is the proportion of fish passing the dam at the spillway out of total project passage. However, by definition in the Fish Accords, spill passage efficiency includes passage the spillway and the ice and trash sluiceway at The Dalles Dam. Traditionally this metric has been termed fish passage efficiency, which is also presented. 
Table ES.3. Survival Study Summary

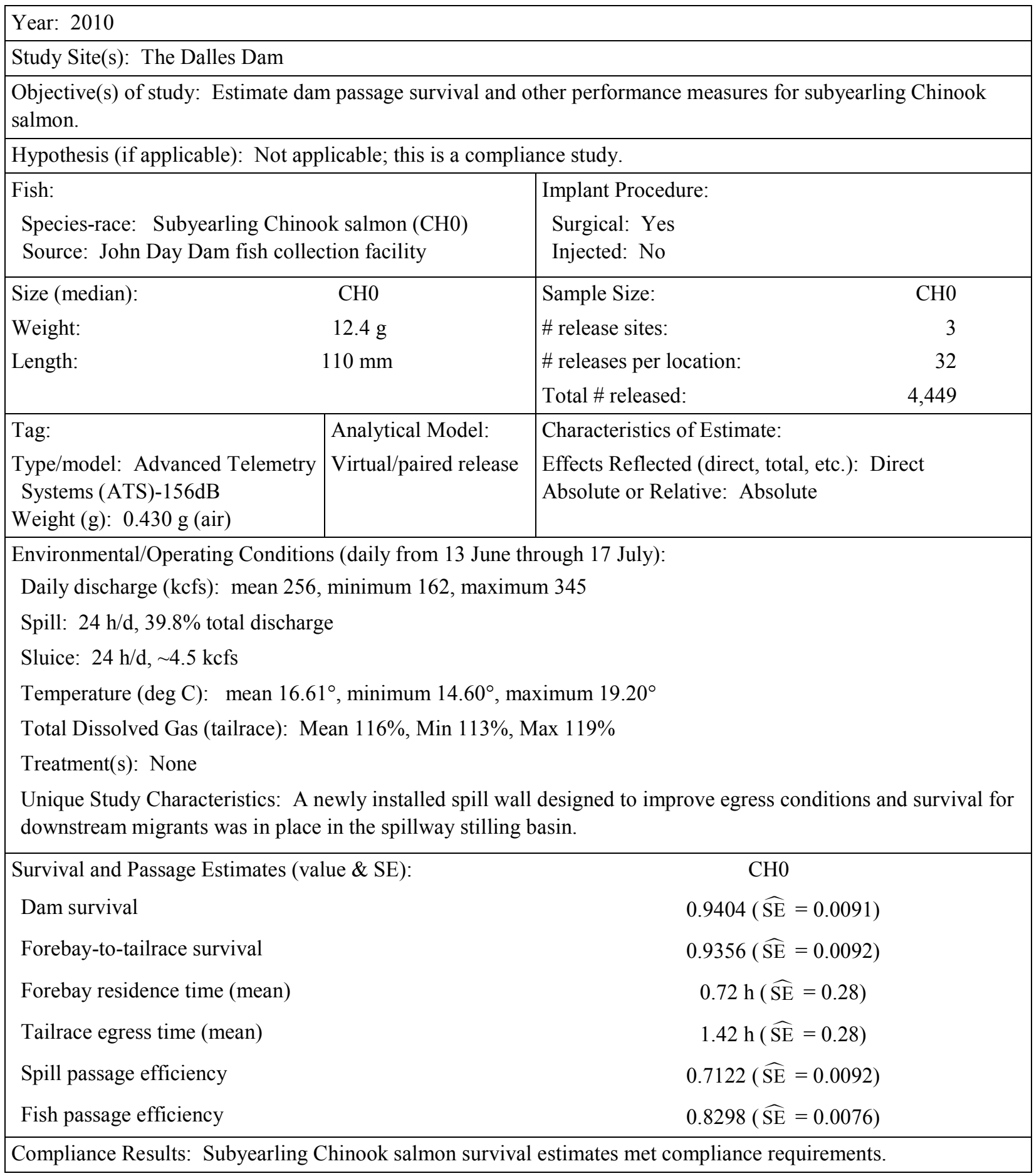




\section{Acknowledgments}

This study was the result of hard work by dedicated scientists from the Pacific Northwest National Laboratory (PNNL), Pacific States Marine Fisheries Commission (PSMFC), the U.S. Army Corps of Engineers, Portland District (USACE), and the University of Washington (UW). Their teamwork and attention to detail, schedule, and budget were essential for the study to succeed in providing high-quality, timely results to decision-makers.

- PNNL: C Arimescu, G Batten, B Bellgraph, R. Brown, S Carpenter, J Carter, K Carter, E Choi, Z Deng, K Deters, G Dirkes, D Faber, E Fischer, T Fu, G Gaulke, K Hall, K Ham, R Harnish, M Hennen, J Hughes, M Hughes, F Khan, J Kim, K Knox, B Lamarche, K Lavender, J Martinez, G McMichael, E Oldenburg, G Ploskey, I Royer, N Tavan, S Titzler, N Trimble, M Weiland, C Woodley, and S Zimmerman.

- UW: J Lady, A Seaburg, R Townsend, and P Westhagen.

- $\quad$ PSMFC: R Martinson, P Kahut, G Kolvachuk, C Anderson, A Cushing, D Etherington, G George, S Goss, T Monter, T Mitchell, R Plante, M Walker, R Wall, M Wilberding.

- USACE: B Eppard, B Cordie, M Langeslay, D Schwartz, M Zyndol, and electricians, operators, and biologists at Bonneville, John Day, and The Dalles dams. 



\section{Acronyms and Abbreviations}

\begin{tabular}{|c|c|}
\hline${ }^{\circ} \mathrm{C}$ & degree(s) Celsius \\
\hline $3 \mathrm{D}$ & three dimensional \\
\hline $\mathrm{BiOp}$ & Biological Opinion \\
\hline BRZ & boat-restricted zone \\
\hline $\mathrm{CHO}$ & subyearling Chinook salmon \\
\hline FCRPS & Federal Columbia River Power System \\
\hline FPE & fish passage efficiency \\
\hline $\mathrm{g}$ & $\operatorname{gram}(\mathrm{s})$ \\
\hline $\mathrm{h}$ & hour(s) \\
\hline JSATS & Juvenile Salmon Acoustic Telemetry System \\
\hline $\mathrm{kcfs}$ & thousand cubic feet per second \\
\hline $\mathrm{km}$ & kilometer(s) \\
\hline $\mathrm{L}$ & liter(s) \\
\hline $\mathrm{m}$ & meter(s) \\
\hline $\mathrm{mg}$ & milligram(s) \\
\hline $\mathrm{mm}$ & millimeter(s) \\
\hline MOA & Memorandum of Agreement \\
\hline PIT & passive integrated transponder \\
\hline PNNL & Pacific Northwest National Laboratory \\
\hline PRI & pulse repetition interval \\
\hline PSMFC & Pacific States Marine Fisheries Commission \\
\hline $\mathrm{rkm}$ & river kilometer(s) \\
\hline $\mathrm{RM}$ & river mile(s) \\
\hline RME & research, monitoring, and evaluation \\
\hline ROR & run-of-river \\
\hline RPA & Reasonable and Prudent Alternative \\
\hline SE & standard error \\
\hline SPE & spill passage efficiency \\
\hline TDA & The Dalles Dam \\
\hline USACE & U.S. Army Corps of Engineers \\
\hline UW & University of Washington \\
\hline
\end{tabular}





\section{Contents}

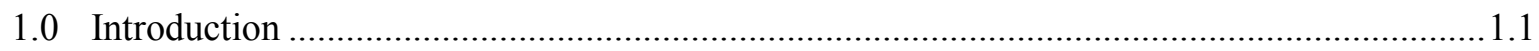

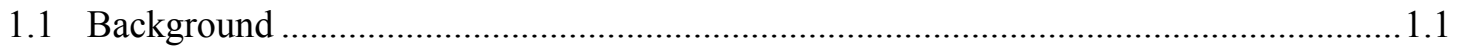

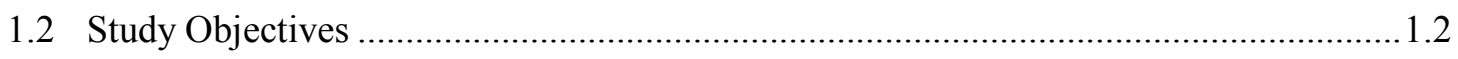

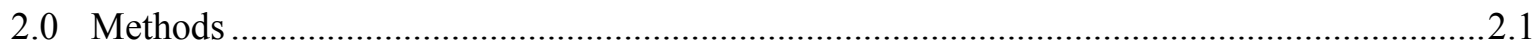

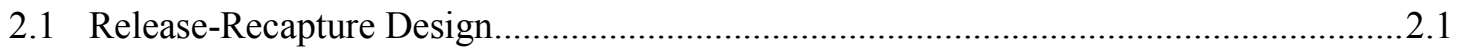

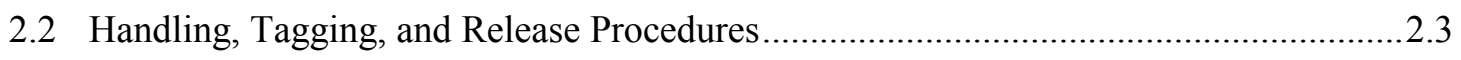

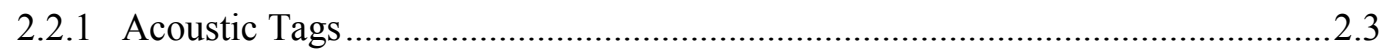

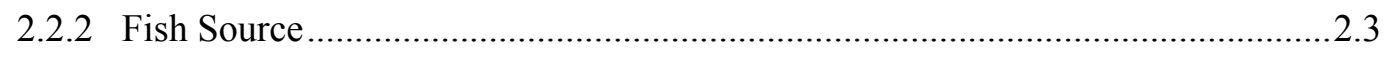

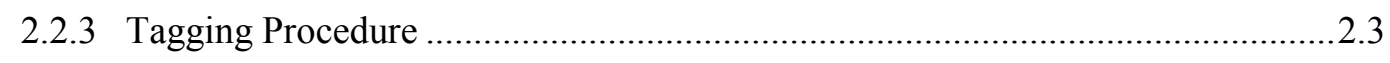

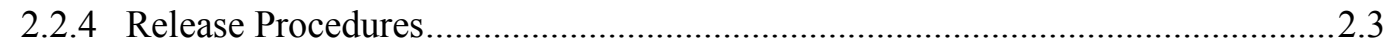

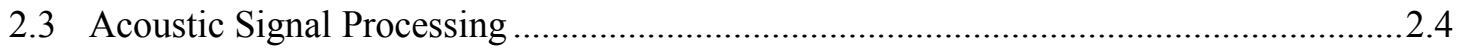

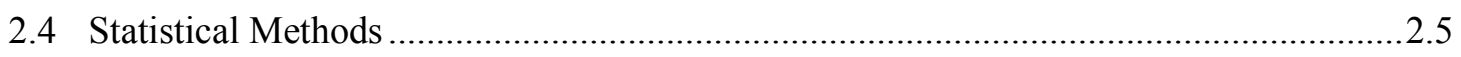

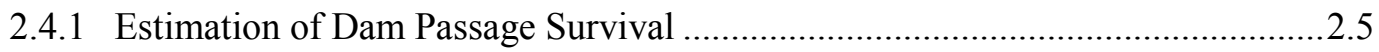

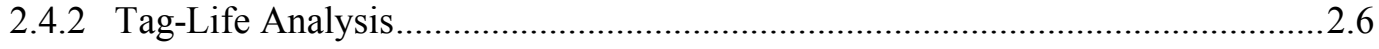

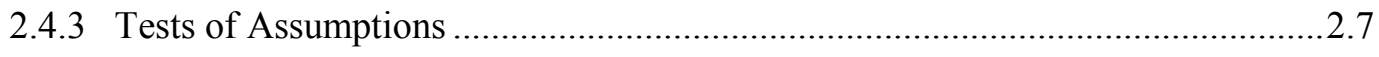

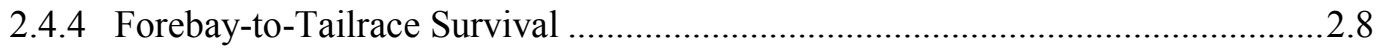

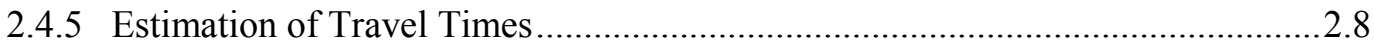

2.4.6 Estimation of Spill Passage Efficiency ……..................................................2.

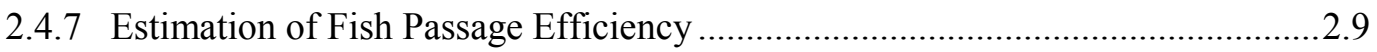

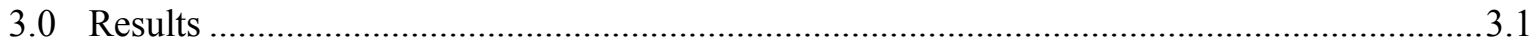

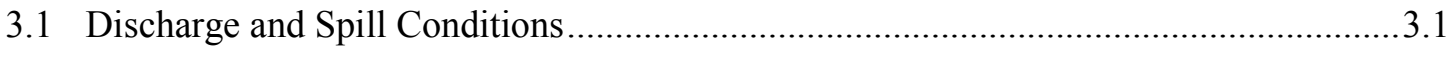

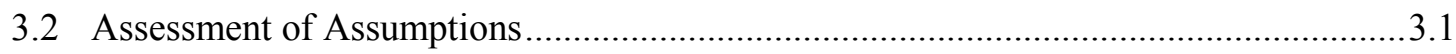

3.2.1 Fish Size Distribution.................................................................................. 3.1

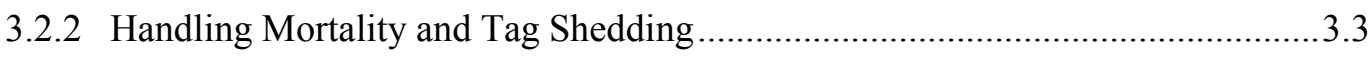

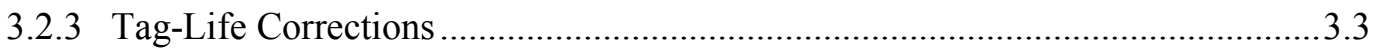

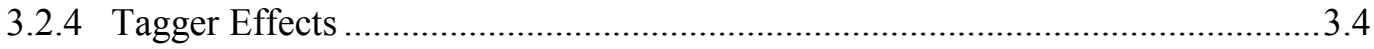

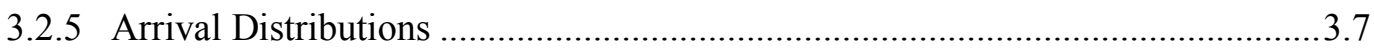

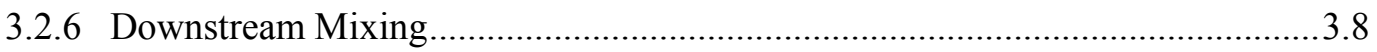

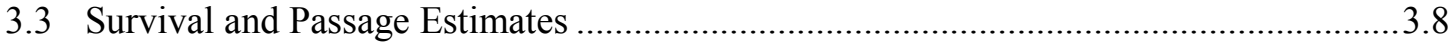

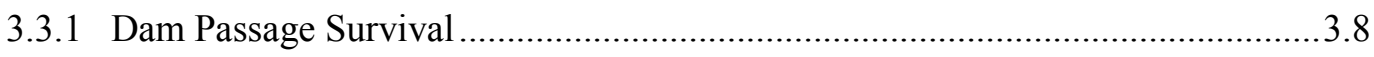

3.3.2 Forebay-to-Tailrace Passage Survival .............................................................10

3.3.3 Forebay Residence Time .............................................................................

3.3.4 Tailrace Egress Time................................................................................. 3.11

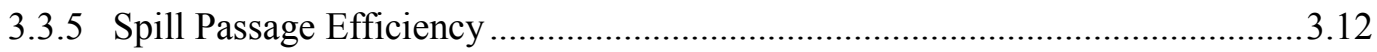

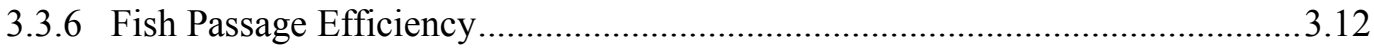

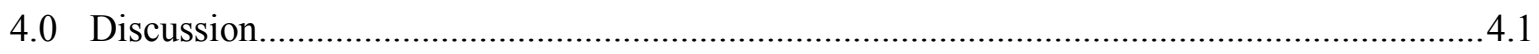




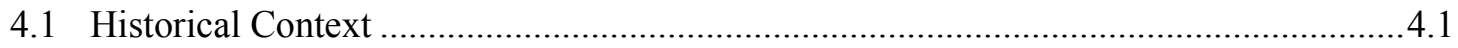

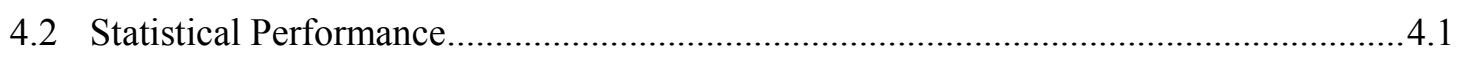

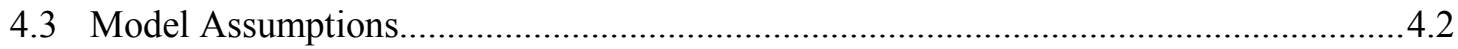

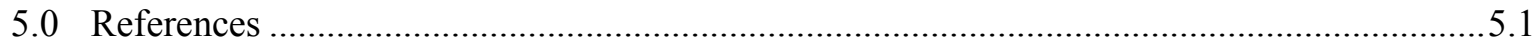

\section{Figures}

Figure 2.1. Schematic of Releases $(R)$ and Detection Locations (dashed lines) Used in Estimating Dam Passage Survival at The Dalles Dam in 2010. Note, the arrays at rkm 311 and rkm 307 are not actually on the BRZ demarcations.

Figure 2.2. Front View Schematic of Hydrophone Deployments at Three Turbines Showing the Double-Detection Arrays. The circles denote the hydrophones of Array 1 and the triangles denote the hydrophones of Array 2.

Figure 3.1. Plot of Modeled Columbia River Discharge in the 2009-2010 Water Year Versus the Modeled 70-Year (1929-1999) Discharge. Historical modeled estimates are from the 2000 Level Modified Flow Report, and modeled estimates for water year 2009-2010 were from the River Forecast Center Runoff Model.

Figure 3.2. Relative Frequency Distributions for Fish Length $(\mathrm{mm})$ of Subyearling Chinook Salmon Smolts Used in (a) Release $V_{1}$, (b) Release $R_{2}$, (c) Release $R_{3}$, and (d) ROR Fish Sampled at John Day Dam by the Fish Passage Center.

Figure 3.3. Range (blue dashed line) and Median (black solid line) Lengths of Acoustic-Tagged Subyearling Chinook Salmon Used in the 2010 Survival Studies. Releases were made daily from June 13 through July 17 at three release locations: Roosevelt (RM 242, rkm 390), The Dalles Dam tailrace (RM 191, rkm 307), and Hood River (RM 171, rkm 275).

Figure 3.4. Individual Failure Times for the $n=50$ Acoustic Tags Used in the Summer Tag-Life Study, Along with the Fitted Four-Parameter Vitality Model of Li and Anderson (2009)......3.4

Figure 3.5. Plot of the Fitted Tag-Life Survivorship Curve and the Arrival-Time Distributions of Subyearling Chinook Salmon Smolts for Releases $V_{1}, R_{2}$, and $R_{3}$ at the Acoustic-Detection Array Located at Rkm 86.0 (Figure 2.1)...

Figure 3.6. Frequency Distribution Plots of Downstream Arriving Timing (expressed as percentages) for Subyearling Chinook Salmon Releases $V_{1}, R_{2}$, and $R_{3}$ at Detection Arrays Located at (a) Rkm 234, (b), Rkm 153, (c) Rkm 113, and (d) Rkm 86. (See Figure 2.1). All times adjusted relative to the release time of $R_{1 . .}$ The distributions averaged over all release groups.

Figure 3.7. Distribution of Forebay Residence Times for Subyearling Chinook Salmon Smolts at The Dalles Dam, 2010 ...

Figure 3.8. Distribution of Tailrace Egress Times for Subyearling Chinook Salmon Smolts at The Dalles Dam, 2010 


\section{Tables}

Table 2.1. Sample Sizes for Acoustic Releases Used in the 2010 Subyearling Chinook Salmon Survival Studies at The Dalles Dam

Table 2.2. Relative Release Times for the Acoustic-Tagged Fish to Accommodate Downstream Mixing. Releases were timed to accommodate the approximately 60 -h travel time between $R_{1}$ and $R_{2}$ and the 13-h travel time between $R_{2}$ and $R_{3}$....

Table 3.1. Number of Subyearling Chinook Salmon Tagged at Each Release Site by Tagger.

Tagger effort was homogeneous $\left(P\left(\chi_{12}^{2} \geq 8.6496\right)=0.7325\right)$

Table 3.2. Reach Survivals By Tagger for Release Groups $R_{1}, R_{2}$, and $R_{3}$. F-tests of homogeneous survivals and associated $P$-values. Numbers in parentheses are ranks among the seven taggers.

Table 3.3. Estimated Probabilities $(L)$ of an Acoustic Tag Being Active When a Subyearling Chinook Salmon Smolt Arrived at a Detection Array Used in Estimating Dam Passage Survival at The Dalles Dam in 2010. For the $V_{1}$ release, the $L$ values are the conditional probability a tag is active, given it was active at the time the group was formed at the detection array at $\mathrm{rkm}$ 309. (Standard errors are in parentheses.).

Table 3.4. Tag-Life-Adjusted Survival Estimates of Reach Survival and Detection Probabilities for Subyearling Chinook Salmon Smolts Used in Estimating Dam Passage Survival at The Dalles Dam in 2010. Parameter estimates based on fully parameterized release-recapture models for each group. Standard errors (SE) based on both the inverse hessian matrix and bootstrapping for key parameters ( $\dagger$ ) and only the inverse hessian matrix for associated parameters $(*)$. 



\subsection{Introduction}

The compliance monitoring study reported here was conducted by researchers at Pacific Northwest National Laboratory (PNNL) and the University of Washington (UW) for the U.S. Army Corps of Engineers, Portland District (USACE). The purpose of the study was to estimate dam passage survival for subyearling Chinook salmon at The Dalles Dam as stipulated by the 2008 Federal Columbia River Power System (FCRPS) Biological Opinion (BiOp; NOAA 2008) and provide additional performance measures at the dam as stipulated in the Columbia Basin Fish Accords (3 Treaty Tribes and Action Agencies 2008).

\subsection{Background}

The 2008 FCRPS BiOp contains a Reasonable and Prudent Alternative (RPA) that includes actions calling for measurements of juvenile salmonid survival (RPAs 52.1 and 58.1). These RPAs are being addressed as part of the federal research, monitoring, and evaluation (RME) effort for the FCRPS BiOp. Most importantly, the FCRPS BiOp includes performance standards for juvenile salmonid survival in the FCRPS against which the Action Agencies (Bonneville Power Administration, Bureau of Reclamation, and USACE) must compare its estimates, as follows (after the RME Strategy 2 of the RPA):

Juvenile Dam Passage Performance Standards - The Action Agencies juvenile performance standards are an average across Snake River and lower Columbia River dams of $96 \%$ average dam passage survival for spring Chinook and steelhead and 93\% average across all dams for Snake River subyearling Chinook. Dam passage survival is defined as survival from the upstream face of the dam to a standardized reference point in the tailrace.

The Columbia Basin Fish Accords were outlined in a Memorandum of Agreement (MOA) between the three lower river tribes and the Action Agencies. The Fish Accords contain three additional requirements relevant to the 2010 survival studies (after the MOA Attachment A):

Dam Survival Performance Standard - Meet the 96\% dam passage survival standard for yearling Chinook and steelhead and the 93\% standard for subyearling Chinook. Achievement of the standard is based on 2 years of empirical survival data ....

$\underline{\text { Spill Passage Efficiency and Delay Metrics }}$ - Spill passage efficiency and delay metrics under current spill conditions ... a are not expected to be degraded ("no backsliding") with installation of new fish passage facilities at the dams ....

Future Research, Monitoring, and Evaluation - The Action Agencies' dam survival studies for purposes of determining juvenile dam passage performance will also collect information about SPE, BRZ-to-BRZ (boat restricted zone) survival and delay, as well as other distribution and survival information. SPE and delay metrics will be considered in the performance check-ins or with Configuration and Operations Plan updates, but not as principal or priority metrics over dam survival performance standards. Once a dam meets the survival performance standard, SPE and delay metrics may be monitored coincidentally with dam survival testing. 
This report summarizes the results of the 2010 summer acoustic-telemetry study of subyearling Chinook salmon at The Dalles Dam to assess the Action Agencies' compliance with the performance criteria of the 2008 FCRPS BiOp and the Fish Accords.

\subsection{Study Objectives}

The purpose of summer 2010 compliance monitoring at The Dalles Dam (TDA) was to estimate performance measures for subyearling Chinook salmon as outlined in the 2008 FCRPS BiOp and the Fish Accords. The following metrics were estimated using the Juvenile Salmon Acoustic Telemetry System (JSATS) technology:

- Dam passage survival, defined as survival from the upstream face of the dam to a standardized reference point in the tailrace. Performance ${ }^{1}$ should be $\geq 93 \%$ survival for subyearling Chinook salmon. Survival should be estimated with a standard error $(\mathrm{SE}) \leq 1.5 \%$.

- Forebay-to-tailrace survival, defined as survival from a forebay array $2 \mathrm{~km}$ upstream of the dam to a tailrace array $2 \mathrm{~km}$ downstream. The forebay-to-tailrace survival estimate satisfies the "BRZ-toBRZ" survival estimate called for in the Fish Accords.

- Forebay residence time, defined as the average time smolts take to travel the last $100 \mathrm{~m}$ upstream of the dam before passing into the dam, i.e., from the 100-m mark to the dam face.

- Tailrace egress time, defined as the average time smolts take to travel from the dam to the downstream tailrace boundary, i.e., tailrace array $2 \mathrm{~km}$ downstream of the dam.

- Spill passage efficiency (SPE), defined as the fraction of fish going through the dam via the spillway $^{2}$.

- Fish passage efficiency (FPE), defined as the fraction of fish going through the dam via the spillway and the sluiceway ${ }^{3}$.

Results are reported by performance measure. This report is designed to provide a succinct and timely summary of BiOp/Fish Accords performance measures for subyearling Chinook salmon. A similar report was presented in October 2010 for yearling Chinook salmon and steelhead (PNNL and UW 2010). A comprehensive technical report scheduled for 2011 will provide detailed data on survival and fish passage for yearling and subyearling Chinook salmon and steelhead at The Dalles Dam in 2010.

\footnotetext{
${ }^{1}$ Performance as defined in the 2008 FCRPS BiOp, Section 6.0.

${ }^{2}$ The definition of spill passage efficiency in the Fish Accords has traditionally been called fish passage efficiency.

${ }^{3}$ This was called spill passage efficiency in the Fish Accords.
} 


\subsection{Methods}

Study methods involved fish release and recapture, the associated fish handling, tagging, and release procedures, acoustic signal processing, and statistical and analytical approaches.

\subsection{Release-Recapture Design}

The release-recapture design used to estimate dam passage survival at The Dalles Dam consisted of a novel combination of a virtual release $\left(V_{1}\right)$ of fish at the face of the dam and a paired release below the dam (Figure 2.1) (Skalski et al. 2010). Tagged fish released above John Day Dam were used to supply a source of fish known to have arrived alive at the face of The Dalles Dam. By releasing the fish far enough upstream, they should have arrived at the dam in a spatial pattern typical of run-of-river (ROR) fish. This virtual-release group was then used to estimate survival through the dam and part of the way through the next reservoir (i.e., river kilometer [rkm] 275) (Figure 2.1). To account and adjust for this extra reach mortality, a paired release below The Dalles Dam (i.e., $R_{2}$ and $R_{3}$ ) (Figure 2.1) was used to estimate survival in that segment of the reservoir below the dam. Dam passage survival was then estimated as the quotient of the survival estimates for the virtual release to that of the paired release. The sizes of the releases of the acoustic-tagged fish used in the dam passage survival estimates are summarized in Table 2.1.

Table 2.1. Sample Sizes of Acoustic-Tag Releases Used in the 2010 Subyearling Chinook Salmon Survival Studies at The Dalles Dam

\begin{tabular}{lc}
\hline \multicolumn{1}{c}{ Release Location } & Released \\
\hline Above John Day $\left(R_{1}\right)$ & 2,849 \\
Virtual Release $\left(V_{1}\right)$ & 2,417 \\
The Dalles Dam Tailrace $\left(R_{2}\right)$ & 800 \\
Bonneville Reservoir $\left(R_{3}\right)$ & 800 \\
\hline
\end{tabular}

The same release-recapture design was also used to estimate forebay-to-tailrace survival, except that the virtual-release group was constructed of fish known to have arrived at the forebay array. The same below-dam paired release was used to adjust for the extra release mortality below the dam as was used to estimate dam passage survival. The double-detection arrays at the face of the dam (Figure 2.2) were sampled as two independent arrays to allow estimation of detection probabilities by route of passage and assign the location of last detection, i.e., the passage route.

The three-dimensional double-detection array at the face of The Dalles Dam used to construct the virtual-release group was also used to identify the passage routes of fish through the dam. These passage-route data were used to calculate SPE and FPE at The Dalles Dam. The 3D tracking data were further used to estimate forebay residence time within the 100-m zone nearest the dam. The fish used in the virtual release at the face of the dam were used to estimate tailrace egress time. 


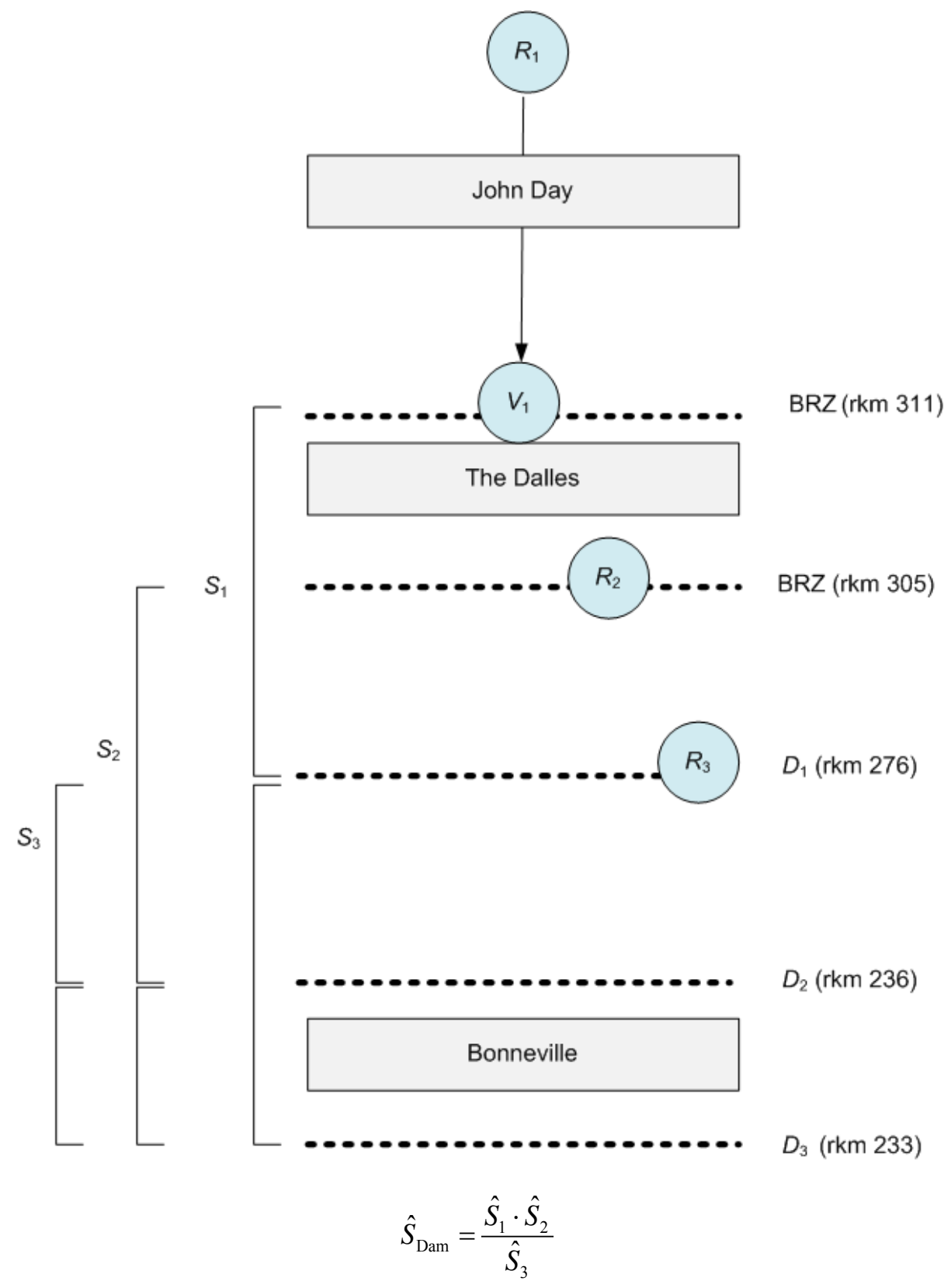

Figure 2.1. Schematic of Releases $(R)$ and Detection Locations (dashed lines) Used in Estimating Dam Passage Survival at The Dalles Dam in 2010. Note, the arrays at rkm 311 and rkm 307 are not actually on the BRZ demarcations.

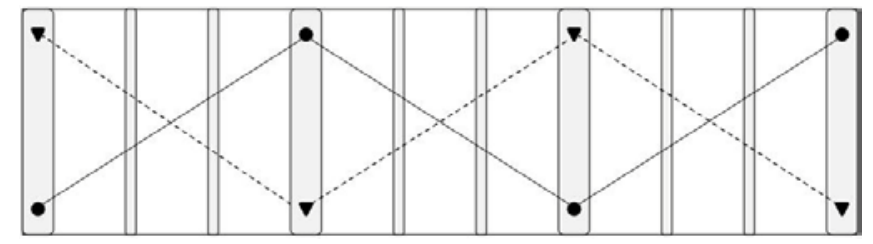

Figure 2.2. Front View Schematic of Hydrophone Deployments at Three Turbines Showing the DoubleDetection Arrays. The circles denote the hydrophones of Array 1 and the triangles denote the hydrophones of Array 2. 
In addition to the detection arrays identified in Figure 2.1, hydrophone arrays were deployed below Bonneville Dam at rkm 49, 37, 22, 8, and 3. These arrays served as potential additional downstream detection arrays to improve precision in the survival analysis for The Dalles Dam.

A total of 50 acoustic tags were randomly sampled from the tags used in the summer season for a taglife assessment. The tags were activated, held in river water, and monitored continuously until they failed. The information from the tag-life study was used to adjust the perceived survival estimates from the Cormack-Jolly-Seber release-recapture model according to the methods of Townsend et al. (2006).

\subsection{Handling, Tagging, and Release Procedures}

Fish obtained from the John Day Dam juvenile bypass system were surgically implanted with JSATS tags, and then transported to three different release points, as described in the following sections.

\subsubsection{Acoustic Tags}

The acoustic tags used in the summer 2010 study were manufactured by Advanced Telemetry Systems. Each tag, model number ATS-156dB, measured $12.02 \mathrm{~mm}$ in length, $5.21 \mathrm{~mm}$ in width, 3.72 $\mathrm{mm}$ in thickness, and weighed $0.430 \mathrm{~g}$ in air. The tags had a nominal transmission rate of 1 pulse every 3 seconds. Nominal tag life was expected to be about 25 days.

\subsubsection{Fish Source}

The subyearling Chinook salmon smolts used in the study were all obtained from the John Day Dam juvenile bypass system. The Pacific States Marine Fisheries Commission diverted fish from the juvenile bypass system into an examination trough, as described by Martinson et al. (2006). Fish $\geq 95 \mathrm{~mm}$ in length without malformations or excessive descaling ( $>20 \%$ total body surface) were selected for tagging.

\subsubsection{Tagging Procedure}

The fish to be tagged were anesthetized in an 18.9-L "knockdown" bucket with fresh river water and MS-222 (tricaine methanesulfonate; $80 \mathrm{mg} / \mathrm{L}$ ). Anesthesia buckets were refreshed repeatedly to maintain the temperature within $\pm 2{ }^{\circ} \mathrm{C}$ of current river temperatures. Each fish was weighed and measured before tagging.

During surgery, each fish was placed ventral side up and a gravity-fed anesthesia supply line was placed into its mouth. The dilution of the "maintenance" anesthesia was $40 \mathrm{mg} / \mathrm{L}$. Using a surgical blade, a 6- to 8-mm incision was made in the body cavity between the pelvic girdle and pectoral fin. A passive integrated transponder (PIT) tag was inserted followed by an acoustic tag. Both tags were inserted toward the anterior end of the fish. The incision was closed using a 5-0 Monocryl suture.

After closing the incision, the fish were placed in a dark 18.9-L transport bucket filled with aerated river water. Fish were held in these buckets for 18 to $24 \mathrm{~h}$ before being transported for release into the river. The loading rate was five fish per bucket.

\subsubsection{Release Procedures}

Tagged fish were transported from John Day Dam by truck to the three release locations (Figure 2.1). Transportation routes were adjusted to provide equal travel times to each release location from John Day 
Dam. Upon arriving at a release site, fish buckets were transferred to a boat for transport to the in-river release location. There were five release locations at each release cross section (Figure 2.1), and equal numbers of buckets of fish were released at each of the five locations for a given cross-section.

Releases occurred for 35 consecutive days (from June 13 to July 17, 2010). Releases alternated between daytime and nighttime, every other day, over the course of the study. The timing of the releases at the three locations was staggered to help facilitate downstream mixing (Table 2.2).

Table 2.2. Relative Release Times for the Acoustic-Tagged Fish to Accommodate Downstream Mixing. Releases were timed to accommodate the approximately 60-h travel time between $R_{1}$ and $R_{2}$ and the 13-h travel time between $R_{2}$ and $R_{3}$.

\begin{tabular}{ccc}
\hline & \multicolumn{2}{c}{ Relative Release Times } \\
\cline { 2 - 3 } Release Location & Daytime Start & Nighttime Start \\
\hline$R_{1}(\operatorname{rkm} 390)$ & Day 1: $0900 \mathrm{~h}$ & Day 2: $2000 \mathrm{~h}$ \\
$R_{2}(\operatorname{rkm~307)}$ & Day 3: $2000 \mathrm{~h}$ & Day 5: $0900 \mathrm{~h}$ \\
$R_{3}(\operatorname{rkm} 275)$ & Day 4: $0900 \mathrm{~h}$ & Day 5: $2200 \mathrm{~h}$ \\
\hline
\end{tabular}

\subsection{Acoustic Signal Processing}

Transmissions of JSATS tag codes received on cabled and autonomous hydrophones were recorded in raw data files. These files were downloaded periodically and transported to PNNL's North Bonneville offices for processing. Receptions of tag codes within raw data files were processed to produce a data set of accepted tag-detection events. For cabled arrays, detections from all hydrophones at a dam were combined for processing. The following three filters were used for data from cabled arrays:

- Multipath filter: For data from each individual cabled hydrophone, all tag-code receptions that occur within 0.156 seconds after an initial identical tag code reception were deleted under the assumption that closely lagging signals are multipath. Initial code receptions were retained. The delay of 0.156 seconds was the maximum acceptance window width for evaluating a pulse repetition interval (PRI) and was computed as 2(PRI_Window+12×PRI_Increment). Both PRI_Window and PRI_Increment were set at 0.006 , which was chosen to be slightly larger than the potential rounding error in estimating PRI to two decimal places.

- Multi-detection filter: Receptions were retained only if the same tag code was received at another hydrophone in the same array within 0.3 seconds because receptions on separate hydrophones within 0.3 seconds (about $450 \mathrm{~m}$ of range) were likely from a single tag transmission.

- PRI filter. Only those series of receptions of a tag code (or "messages") that were consistent with the pattern of transmissions from a properly functioning JSATS acoustic tag were retained. Filtering rules were evaluated for each tag code individually, and it was assumed that only a single tag would be transmitting that code at any given time. For the cabled system, the PRI filter operated on a message, which included all receptions of the same transmission on multiple hydrophones within 0.3 seconds. Message time was defined as the earliest reception time across all hydrophones for that message. Detection required that at least six messages were received with an appropriate time interval between the leading edges of successive messages. 
Like the cabled-array data, receptions of JSATS tag codes within raw autonomous node data files are processed to produce a dataset of accepted tag detection events. A single file is processed at a time, and no information on receptions at other nodes is used. The following two filters are employed during processing of autonomous node data:

- Multipath Filter: Same as for the cabled-array data.

- PRI Filter: Retain only those series of receptions of a tag code (or "hits") that were consistent with the pattern of transmissions from a properly functioning JSATS acoustic tag. Each tag code was processed individually, and it was assumed that only a single tag will be transmitting that code at any given time.

The output of the filtering processes for both cabled and autonomous hydrophones was a data set of events that summarized accepted tag detections for all times and locations where hydrophones were operating. Each unique event record included a basic set of fields that indicated the unique identification number of the fish, the first and last detection time for the event, the location of detection, and how many messages were detected within the event. This list was combined with accepted tag detections from the autonomous arrays and PIT-tag detections for additional quality assurance/quality control analysis prior to survival analysis. Additional fields capture specialized information, where available. One such example was route of passage, which was assigned a value for those events that immediately precede passage at a dam based on spatial tracking of tagged fish movements to a location of last detection. Multiple receptions of messages within an event can be used to triangulate successive tag position relative to hydrophone locations.

One of the most important quality control steps was to examine the chronology of detections of every tagged fish on all arrays above and below the dam-face array to identify any detection sequences that deviate from the expected upstream to downstream progression through arrays in the river. Except for possible detections on forebay entrance arrays after detection on a nearby dam-face array 1 to $3 \mathrm{~km}$ downstream, apparent upstream movements of tagged fish between arrays that were greater than $5 \mathrm{~km}$ apart or separated by one or more dams were very rare $(<0.015 \%)$ and probably represented false positive detections on the upstream array. False positive detections usually will have close to the minimum number of messages and were deleted from the event data set before survival analysis.

Three-dimensional tracking of JSATS-tagged fish in the immediate forebay of The Dalles Dam was used to determine routes of passage to estimate spill passage efficiency. Acoustic tracking is a common technique in bioacoustics based on time-of-arrival differences among different hydrophones. Usually, the process requires a three-hydrophone array for 2D tracking and a four-hydrophone array for 3D tracking. For this study, only 3D tracking was performed. The methods were similar to those described by Weiland et al. (2010) for John Day Dam.

\subsection{Statistical Methods}

\subsubsection{Estimation of Dam Passage Survival}

Maximum likelihood estimation was used to estimate dam passage survival at The Dalles Dam. The capture histories from all of the replicate releases, both daytime and nighttime, were pooled for the 
analysis to produce a single season-wide estimate of survival. A joint likelihood model was used to estimate dam passage survival based on the virtual and paired releases corrected for tag life.

The estimate of dam passage survival was computed as a function of three independent reach survival estimates (Figure 2.1) corrected for the probabilities the acoustic tags were still active, i.e.,

$$
\hat{S}_{\text {Dam }}=\frac{\left(\frac{\hat{S}_{1}}{\hat{L}_{1}}\right)}{\left(\frac{\left(\frac{\hat{S}_{2}}{\hat{L}_{2}}\right)}{\left(\frac{\hat{S}_{3}}{\hat{L}_{3}}\right)}\right)}=\left(\frac{\hat{S}_{1} \hat{S}_{3}}{\hat{S}_{2}}\right) \cdot\left(\frac{\hat{L}_{2}}{\hat{L}_{1} \hat{L}_{3}}\right)
$$

where $\hat{L}_{i}=$ estimated probability an acoustic tag is still active associated with reach survival estimate $\hat{S}_{i}$.

The joint likelihood used to model the three release groups was fully parameterized. Each release was allowed to have unique survival and detection parameters. The fully parameterized model was chosen for purposes of robustness despite empirical evidence that downstream survival and detection probabilities were likely homogeneous. The variance estimate for $\hat{S}_{\text {Dam }}$ takes into account both the release-recapture sampling error and the error in the tag-life estimates according to Townsend et al. (2006). All calculations were performed using Program ATLAS (http://www.cbr.washington.edu/paramest/atlas/) and cross-verified using R and/or Program USER (http://www.cbr.washington.edu/paramest/user/).

\subsubsection{Tag-Life Analysis}

The 50 acoustic tags systematically sampled from the tags used in the subyearling Chinook salmon study were monitored continuously until tag failure. Those failure times were fit to the four-parameter vitality model of $\mathrm{Li}$ and Anderson (2009). The vitality model tends to fit acoustic-tag failure times well, because it allows for both early onset of random failure due to manufacturing as well as systematic battery failure later on.

The probability density function for the vitality model can be written as

$$
f(t)=1-\left(\Phi\left(\frac{1-r t}{\sqrt{u^{2}+s^{2} t}}\right)-e^{\left(\frac{2 u^{2} r^{2}}{s^{4}}+\frac{2 r}{s^{2}}\right)} \Phi\left(\frac{2 u^{2} r+r t+1}{\sqrt{u^{2}+s^{2} t}}\right)\right)^{e^{-k t}}
$$

where: $\Phi=$ cumulative normal distribution,

$r=$ average wear rate of components,

$s=$ standard deviation in wear rate,

$k=$ rate of accidental failure,

$u=$ standard deviation in quality of original components. 
The random failure component, in addition to battery discharge, gives the vitality model additional latitude to fit tag-life data not found in other failure-time distributions such as the Weibull or Gompertz. Parameter estimation was based on maximum likelihood estimation.

For the virtual-release group $\left(V_{1}\right)$ based on fish known to have arrived at the dam and with active tags, the conditional probability of tag activation, given the tag was active at the detection array at rkm 309, was used in the tag-life adjustment for that release group. The conditional probability of tag activation at time $t_{1}$, given it was active at time $t_{0}$, was computed by the quotient:

$$
P\left(t_{1} \mid t_{0}\right)=\frac{S\left(t_{1}\right)}{S\left(t_{0}\right)} .
$$

\subsubsection{Tests of Assumptions}

\subsubsection{Burnham et al. (1987) Tests}

Tests 2 and 3 of Burnham et al. (1987) have been used to assess whether upstream detection history has an effect on downstream survival. Such tests are most appropriate when fish are physically recaptured or segregated during capture as in the case with PIT-tagged fish going through the juvenile bypass system. However, acoustic-tag studies do not use physical recaptures to detect fish. Consequently, there is little or no relevance of these tests in acoustic-tag studies. Furthermore, the very high detection probabilities present in acoustic-tag studies frequently preclude calculation of these tests. For these reasons, these tests were not performed.

\subsubsection{Tests of Mixing}

Evaluation of homogeneous arrival of release groups at downriver detection sites was based on graphs of arrival distributions. The graphs were used to identify any systematic and meaningful departures from mixing. Ideally, the arrival distributions should overlap one another with similarly timed modes.

\subsubsection{Tagger Effects}

Subtle differences in handling and tagging techniques can have an effect on the survival of acoustictagged smolts used in the estimation of dam passage survival. For this reason, tagger effects were evaluated. The single release-recapture model was used to estimate reach survivals for fish tagged by different individuals. The analysis evaluated whether any consistent pattern of reduced reach survivals existed for fish tagged by any of the tagging staff.

For $k$ independent reach survival estimates, a test of equal survival was performed using the $F$-test

$$
F_{k-1, \infty}=\frac{s_{\hat{S}}^{2}}{\left(\frac{\sum_{i=1}^{k} \operatorname{Var}\left(\hat{S}_{i} \mid S_{i}\right)}{k}\right)}
$$


where

$$
s_{\hat{S}}^{2}=\frac{\sum_{i=1}^{k}\left(\hat{S}_{i}-\hat{\bar{S}}\right)^{2}}{k-1}
$$

and

$$
\hat{\bar{S}}=\frac{\sum_{i=1}^{k} \hat{S}_{i}}{k}
$$

The F-test was used in evaluating tagger effects.

\subsubsection{Forebay-to-Tailrace Survival}

The same virtual/paired release methods used to estimate dam passage were also used to estimate forebay-to-tailrace survival. The only distinction was the virtual release group $\left(V_{1}\right)$ was composed of fish known to have arrived alive at the forebay array (rkm 311) of The Dalles Dam instead of at the dam face (Figure 2.1).

\subsubsection{Estimation of Travel Times}

Travel times associated with forebay residence and tailrace egress were estimated using arithmetic averages, i.e.,

$$
\bar{t}=\frac{\sum_{i=1}^{n} t_{i}}{n},
$$

with the variance of $\bar{t}$ estimated by

$$
\widehat{\operatorname{Var}}(\bar{t})=\frac{\sum_{i=1}^{n}\left(t_{i}-\bar{t}\right)^{2}}{n(n-1)},
$$

and where $t_{i}$ was the travel time of the $i^{\text {th }}$ fish $(i=1, \ldots, n)$.

The estimated tailrace egress time was based on the time from last detection of a fish at the double array at the dam face at The Dalles Dam to the first detector at the tailrace array $2 \mathrm{~km}$ downstream of the dam. The estimated forebay residence times were based on the time from the first detection within $100 \mathrm{~m}$ of the dam face to the last detection at the double array in front of The Dalles Dam.

\subsubsection{Estimation of Spill Passage Efficiency}

Spill passage efficiency was estimated by the fraction

$$
\widehat{\mathrm{SPE}}=\frac{\hat{N}_{S D}}{\hat{N}_{S P}+\hat{N}_{S L}+\hat{N}_{T}},
$$


where $\hat{N}_{i}$ is the estimated abundance of acoustic-tagged fish through the $i$ th route ( $i=$ spillway [SP], sluiceway, $[\mathrm{SL}]$, or turbines $[\mathrm{T}]$ ). The double-detection array was used to estimate absolute abundance $(N)$ through a route using the single mark-recapture model (Seber 1982:60) independently at each route. Calculating the variance in stages, the variance of $\widehat{\mathrm{SPE}}$ was estimated as

$$
\operatorname{Var}(\widehat{\mathrm{SPE}})=\frac{\widehat{\mathrm{SPE}}(1-\widehat{\mathrm{SPE}})}{\sum_{i=1}^{3} \hat{N}_{i}}+\widehat{\mathrm{SPE}}^{2}(1-\widehat{\mathrm{SPE}})^{2} \cdot\left[\frac{\operatorname{Var}\left(\hat{N}_{T}\right)+\operatorname{Var}\left(\hat{N}_{S L}\right)}{\left(\hat{N}_{T}+\hat{N}_{S L}\right)^{2}}+\frac{\widehat{\operatorname{Var}}\left(\hat{N}_{S P}\right)}{\hat{N}_{S P}^{2}}\right]
$$

\subsubsection{Estimation of Fish Passage Efficiency}

Fish passage efficiency ${ }^{1}$ was estimated by the fraction

$$
\widehat{\mathrm{FPE}}=\frac{\hat{N}_{S P}+\hat{N}_{S L}}{\hat{N}_{S P}+\hat{N}_{S L}+\hat{N}_{T}}
$$

Calculating the variance in stages, the variance of $\widehat{\mathrm{FPE}}$ was estimated as

$$
\operatorname{Var}(\widehat{\mathrm{FPE}})=\frac{\widehat{\mathrm{FPE}}(1-\widehat{\mathrm{FPE}})}{\sum_{i=1}^{3} \hat{N}_{i}}+\widehat{\mathrm{FPE}}^{2}(1-\widehat{\mathrm{FPE}})^{2} \cdot\left[\frac{\operatorname{Var}\left(\hat{N}_{S P}\right)+\operatorname{Var}\left(\hat{N}_{S L}\right)}{\left(\hat{N}_{S P}+\hat{N}_{S L}\right)^{2}}+\frac{\widehat{\operatorname{Var}}\left(\hat{N}_{T}\right)}{\hat{N}_{T}^{2}}\right]
$$

\footnotetext{
${ }^{1}$ FPE was called spill passage efficiency in the Fish Accords.
} 



\subsection{Results}

The results cover discharge and spill conditions, assessment of assumptions, and survival and passage estimates.

\subsection{Discharge and Spill Conditions}

Monthly discharge at The Dalles Dam in 2010 peaked during June at $488 \mathrm{kcfs}$ (Figure 3.1). In general, 2010 discharge was lower than the 70-year average during spring and similar during summer. During the summer study (13 June through 17 July 2010), daily total project discharge averaged $256 \mathrm{kcfs}$ and ranged between 162 and $345 \mathrm{kcfs}$. The spill percentage out of total project discharge during summer study was $39.8 \%$.

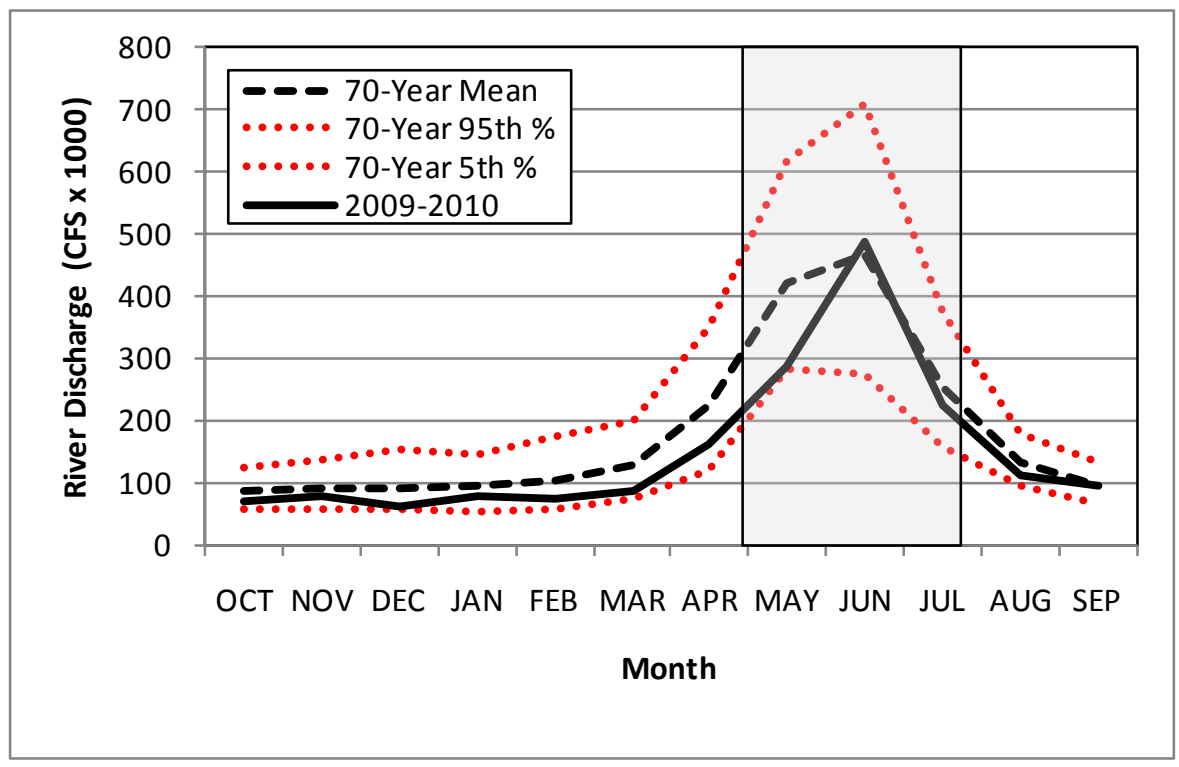

Figure 3.1. Plot of Modeled Columbia River Discharge in the 2009-2010 Water Year Versus the Modeled 70-Year (1929-1999) Discharge. Historical modeled estimates are from the 2000 Level Modified Flow Report, and modeled estimates for water year 2009-2010 were from the River Forecast Center Runoff Model.

\subsection{Assessment of Assumptions}

The assessment of assumptions covers fish size distribution, tag-life-corrections, handling mortality and tag shedding, tagger effects, arrival distributions, and downstream mixing.

\subsubsection{Fish Size Distribution}

Comparison of acoustic-tagged fish with ROR fish sampled at John Day Dam through the Smolt Monitoring Program shows that the length frequency distributions were generally well-matched for 
subyearling Chinook salmon (Figure 3.2). The tagged fish had less representation in the 95-100 and 105$110 \mathrm{~mm}$ categories than the ROR fish. No fish below $95 \mathrm{~mm}$ were tagged. The length distributions for the three subyearling Chinook salmon releases (Figure 3.2) were quite similar. Median length for acoustic-tagged subyearling Chinook salmon was $110 \mathrm{~mm}$. Median length of fish tagged across the course of the study remained stable over time (Figure 3.3).
a. Release $V_{1}$
b. Release $R_{2}$
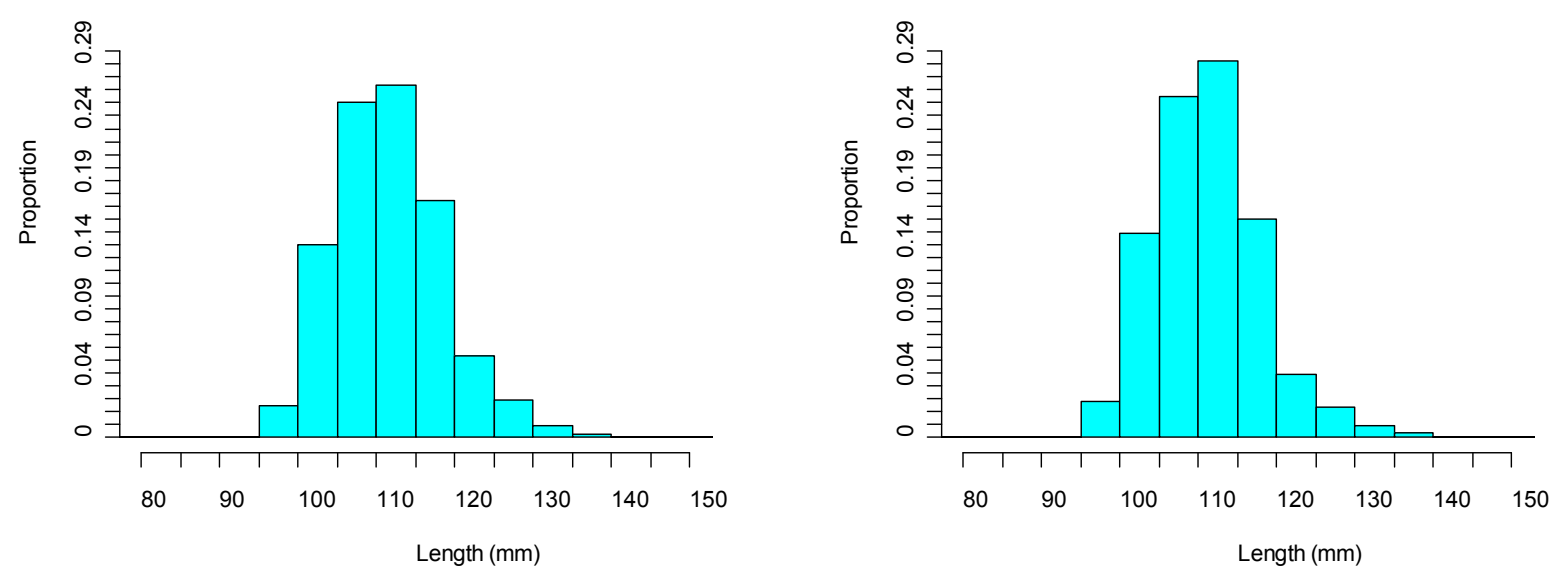

c. Release $R_{3}$

d. ROR fish sampled at John Day Dam
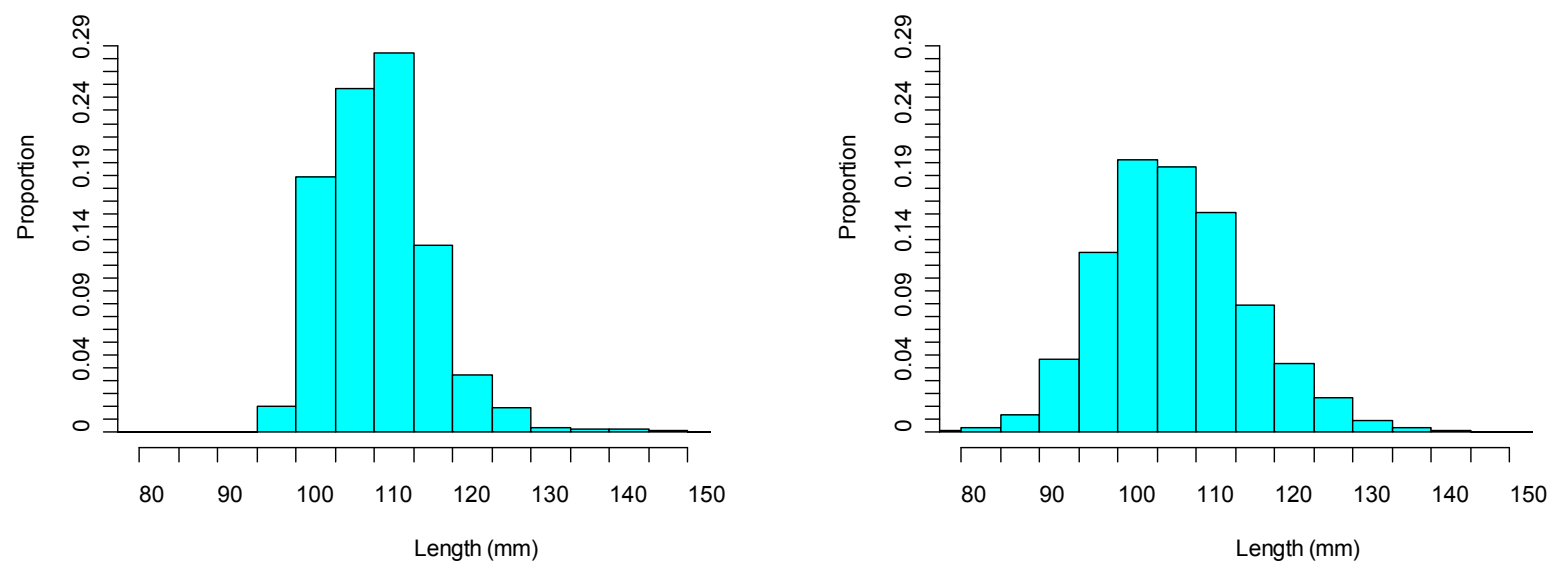

Figure 3.2. Relative Frequency Distributions for Fish Length ( $\mathrm{mm}$ ) of Subyearling Chinook Salmon Smolts Used in (a) Release $V_{1}$, (b) Release $R_{2}$, (c) Release $R_{3}$, and (d) ROR Fish Sampled at John Day Dam by the Fish Passage Center 


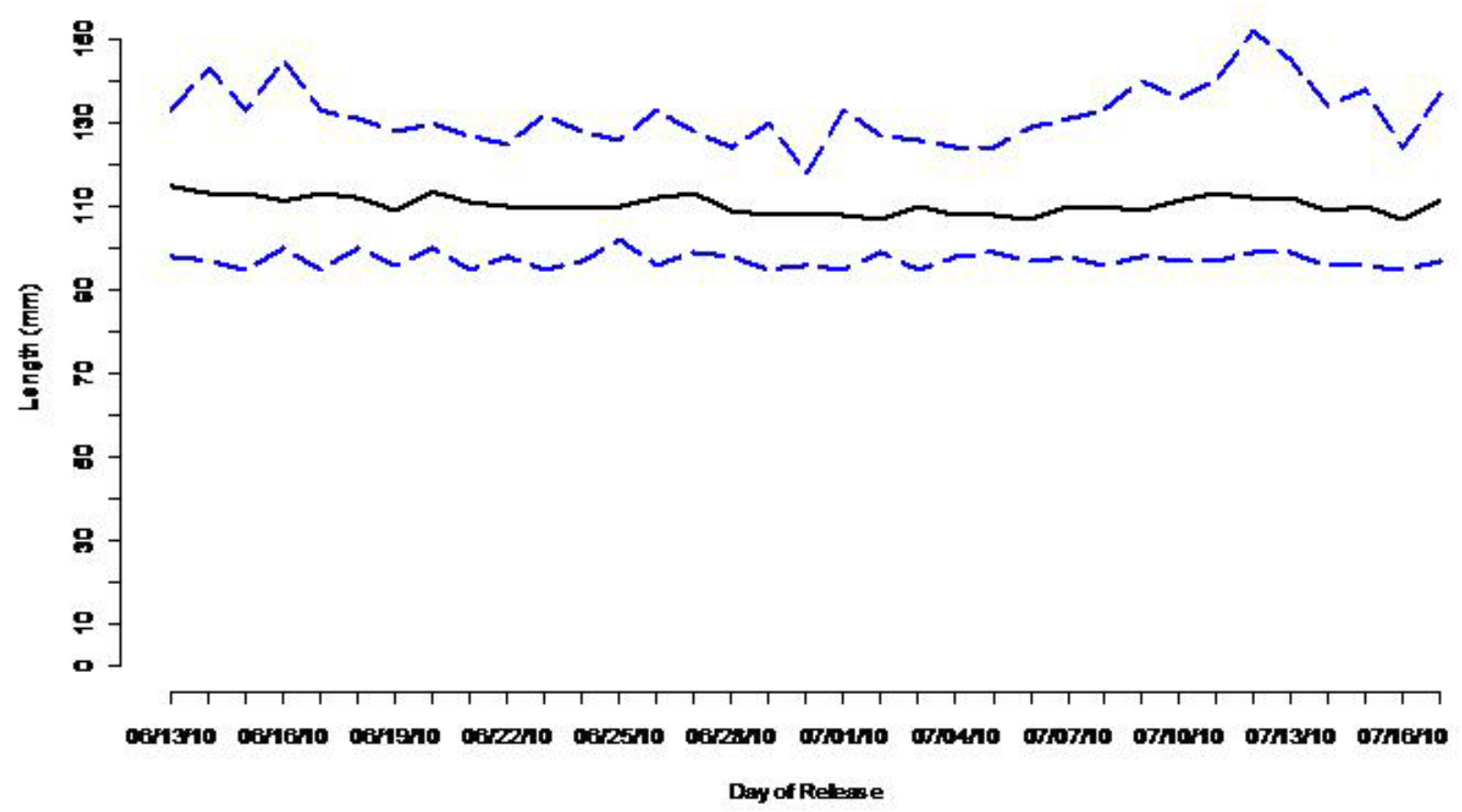

Figure 3.3. Range (blue dashed line) and Median (black solid line) Lengths of Acoustic-Tagged Subyearling Chinook Salmon Used in the 2010 Survival Studies. Releases were made daily from June 13 through July 17 at three release locations: Roosevelt (RM 242, rkm 390), The Dalles Dam tailrace (RM 191, rkm 307), and Hood River (RM 171, rkm 275).

\subsubsection{Handling Mortality and Tag Shedding}

Fish were held for $24 \mathrm{~h}$ prior to release. The 24 - $\mathrm{h}$ tagging mortality in summer was $0.23 \%$. No tags were shed during the 24 -h holding period.

\subsubsection{Tag-Life Corrections}

Mean tag life $(n=50)$ was 35.54 days. The earliest tag failure was at 31.27 days and the longest at 40.13 days. The failure-time data for the acoustic tags was fit to a four-parameter vitality model of Li and Anderson (2009). The maximum likelihood estimates for the four model parameters were $\hat{r}=0.028261$, $\hat{s}=-2.91111 \times 10^{-9}, \hat{k}=0$, and $\hat{u}=0.058789$ (Figure 3.4). This tag-life survivorship model was subsequently used to estimate the probabilities of tag failure and provide tag-life-adjusted estimates of smolt survival. 


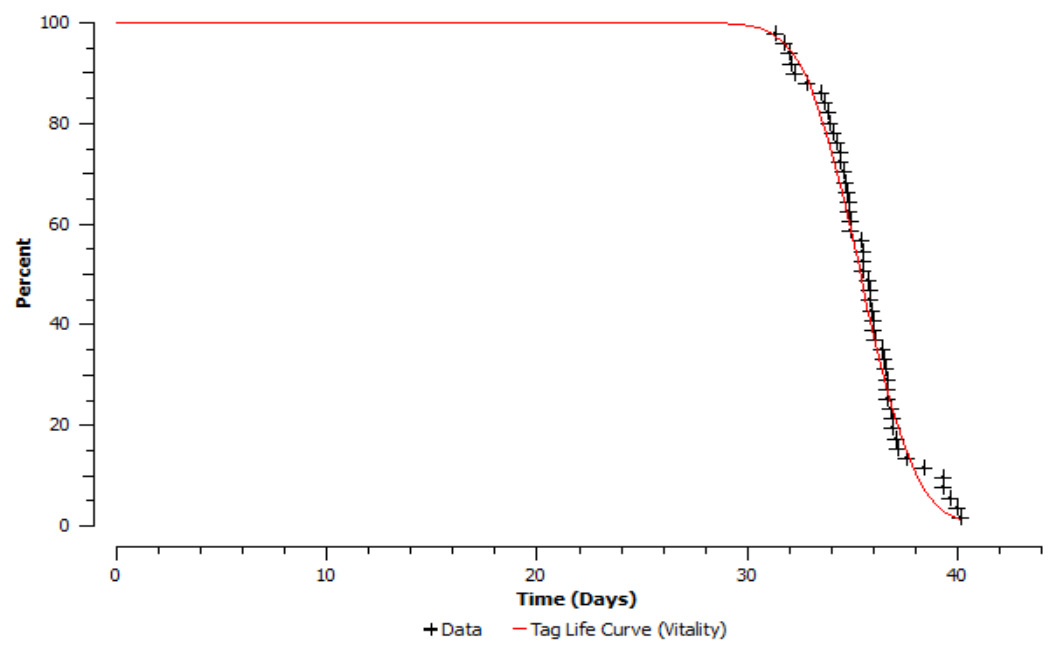

Figure 3.4. Individual Failure Times for the $n=50$ Acoustic Tags Used in the Summer Tag-Life Study, Along with the Fitted Four-Parameter Vitality Model of Li and Anderson (2009)

\subsubsection{Tagger Effects}

Having various fish handlers tag the same proportions of fish for release at each of the release sites can help minimize but did not necessarily eliminate handling effects in the estimate of dam passage survival. The study was therefore designed to balance tagger effort across locations. Implementation produced near perfect balance for the tagged subyearling Chinook salmon (Table 3.1).

Table 3.1. Number of Subyearling Chinook Salmon Tagged at Each Release Site by Tagger. Tagger effort was homogeneous $\left(P\left(\chi_{12}^{2} \geq 8.6496\right)=0.7325\right)$

\begin{tabular}{ccccccccr}
\hline & \multicolumn{7}{c}{ Tagger } & Total \\
\cline { 2 - 7 } Release Location & $\mathrm{A}$ & $\mathrm{B}$ & $\mathrm{C}$ & $\mathrm{D}$ & $\mathrm{E}$ & $\mathrm{F}$ & $\mathrm{G}$ & 2,849 \\
\hline$R_{1}$ & 436 & 489 & 463 & 454 & 171 & 369 & 467 & 800 \\
$R_{2}$ & 132 & 135 & 116 & 123 & 40 & 108 & 146 & 800 \\
$R_{3}$ & 131 & 133 & 128 & 119 & 35 & 115 & 139 & 4,449 \\
\hline Total Tags & 699 & 757 & 707 & 696 & 246 & 592 & 752 & 4 \\
\hline
\end{tabular}

To further assess whether tagger effects may have occurred, reach survivals for the fish tagged by the different staff were calculated using the Cormack-Jolly Seber single release-recapture model (Table 3.2). Significant $(P<0.05$. $)$ heterogeneity was detected. However, further examination indicated that seasonal trends in survival were confounding attempts to assess the presence of tagger effects using the $F$-tests because the effect of the various taggers was not evenly distributed across the course of the study. Fish tagged by tagger $\mathrm{G}$ had lower survivals because that staff member only tagged fish towards the end of the season. Fish tagged by tagger B had very good survival because that staff member only tagged fish at the beginning of the study. The remaining taggers had fish with intermediate survivals because they tagged fish more or less across the breadth of the season. The fish tagged by different staff during the same time were examined; survivals were homogeneous with no obvious evidence of any tagger effect. Therefore, fish tagged by all taggers were included in the analysis for this report. 
Table 3.2. Reach Survivals By Tagger for Release Groups $R_{1}, R_{2}$, and $R_{3}$. F-tests of homogeneous survivals and associated $P$-values. Numbers in parentheses are ranks among the seven taggers.

\begin{tabular}{|c|c|c|c|c|c|c|c|c|c|c|c|c|c|}
\hline \multirow{3}{*}{$\begin{array}{c}\text { Release } \\
\text { Site }\end{array}$} & \multirow[b]{3}{*}{ Tagger } & \multicolumn{12}{|c|}{ Cormack-Jolly-Seber Survival } \\
\hline & & \multicolumn{2}{|c|}{ Release to Rkm 309} & \multicolumn{2}{|c|}{$\mathrm{Rkm} 309$ to 275} & \multicolumn{2}{|c|}{$\mathrm{Rkm} 275$ to 234} & \multicolumn{2}{|c|}{$\mathrm{Rkm} 234$ to 153} & \multicolumn{2}{|c|}{$\mathrm{Rkm} 153$ to 113} & \multicolumn{2}{|c|}{$\mathrm{Rkm} 113$ to 86} \\
\hline & & Estimate & SE & Estimate & SE & Estimate & SE & Estimate & SE & Estimate & SE & Estimate & SE \\
\hline \multirow{7}{*}{$R_{1}$} & A & $0.8395(5)$ & 0.0177 & $0.9141(4)$ & 0.0147 & $0.9671(5)$ & 0.0104 & $0.9426(4)$ & 0.0138 & $0.9810(4)$ & 0.0086 & $0.9912(4)$ & 0.0061 \\
\hline & $\mathrm{B}$ & $0.8938(2)$ & 0.0141 & $0.9394(3)$ & 0.0115 & $1.0000(2)$ & 0.0044 & $0.9592(2)$ & 0.0102 & $0.9909(2)$ & 0.0052 & $0.9980(3)$ & 0.0023 \\
\hline & $\mathrm{C}$ & $0.8522(4)$ & 0.0165 & $0.9465(2)$ & 0.0114 & $1.0000(2)$ & 0.0000 & $0.9195(5)$ & 0.0142 & $0.9965(1)$ & 0.0034 & $0.9989(2)$ & 0.0045 \\
\hline & D & $0.8027(6)$ & 0.0187 & $0.9033(5)$ & 0.0155 & $0.9520(6)$ & 0.0124 & $0.9126(6)$ & 0.0168 & $0.9732(5)$ & 0.0106 & $0.9746(6)$ & 0.0101 \\
\hline & $\mathrm{E}$ & $0.9357(1)$ & 0.0188 & $0.9562(1)$ & 0.0162 & $1.0000(2)$ & 0.0000 & $0.9782(1)$ & 0.0133 & $0.9822(3)$ & 0.0125 & $1.0000(1)$ & 0.0096 \\
\hline & $\mathrm{F}$ & $0.8910(3)$ & 0.0163 & $0.9016(6)$ & 0.0165 & $0.9879(4)$ & 0.0068 & $0.9500(3)$ & 0.0135 & $0.9722(6)$ & 0.0107 & $0.9787(5)$ & 0.0094 \\
\hline & G & $0.7795(7)$ & 0.0194 & $0.8908(7)$ & 0.0165 & $0.9515(7)$ & 0.0138 & $0.8806(7)$ & 0.0198 & $0.9692(7)$ & 0.0111 & $0.9648(7)$ & 0.0117 \\
\hline \multirow{2}{*}{ All Taggers } & $F$-test & 9.8531 & & 2.9625 & & 6.8130 & & 4.9085 & & 1.1627 & & 2.8155 & \\
\hline & $P$-value & $<0.0001$ & & 0.0068 & & $<0.0001$ & & $<0.0001$ & & 0.3229 & & 0.0097 & \\
\hline \multirow{2}{*}{$\begin{array}{l}\text { Tagger G } \\
\text { Omitted }\end{array}$} & $F$-test & 7.5949 & & 2.6425 & & 7.6624 & & 3.1904 & & 1.1168 & & 2.1171 & \\
\hline & $P$-value & $<0.0001$ & & 0.0215 & & $<0.0001$ & & 0.0070 & & 0.3487 & & 0.0603 & \\
\hline & & \multicolumn{12}{|c|}{ Cormack-Jolly-Seber Survival } \\
\hline \multirow{2}{*}{$\begin{array}{l}\text { Release } \\
\text { Site }\end{array}$} & \multirow[b]{2}{*}{ Tagger } & & & \multicolumn{2}{|c|}{ Release 309 to 275} & \multicolumn{2}{|c|}{$\mathrm{Rkm} 275$ to 234} & \multicolumn{2}{|c|}{ Rkm 234 to 153} & \multicolumn{2}{|c|}{ Rkm 153 to 113} & \multicolumn{2}{|c|}{$\mathrm{Rkm} 113$ to 86} \\
\hline & & & & Estimate & SE & Estimate & $\mathrm{SE}$ & Estimate & SE & Estimate & SE & Estimate & $\mathrm{SE}$ \\
\hline \multirow{7}{*}{$R_{2}$} & A & & & $0.9924(3)$ & 0.0074 & $0.9807(5)$ & 0.0132 & $0.9511(5)$ & 0.0201 & $0.9925(4.5)$ & 0.0098 & $0.9761(4)$ & 0.0155 \\
\hline & $\mathrm{B}$ & & & $0.9704(7)$ & 0.0146 & $0.9874(2)$ & 0.0108 & $0.9619(4)$ & 0.0183 & $0.9814(6)$ & 0.0136 & $0.9842(3)$ & 0.0121 \\
\hline & $\mathrm{C}$ & & & $0.9914(5)$ & 0.0085 & $0.9806(6)$ & 0.0153 & $0.9421(6)$ & 0.0239 & $0.9925(4.5)$ & 0.0118 & $0.9511(7)$ & 0.0226 \\
\hline & $\mathrm{D}$ & & & $0.9918(4)$ & 0.0080 & $0.9867(3)$ & 0.0116 & $0.9637(3)$ & 0.0178 & $1.0000(2)$ & 0.0175 & $0.9671(5)$ & 0.0170 \\
\hline & $\mathrm{E}$ & & & $1.0000(1.5)$ & 0.0071 & $1.0000(1)$ & 0.0071 & $0.9750(2)$ & 0.0247 & $1.0000(2)$ & 0.0084 & $1.0000(1.5)$ & 0.0072 \\
\hline & $\mathrm{F}$ & & & $1.0000(1.5)$ & 0.0000 & $0.9819(4)$ & 0.0129 & $0.9902(1)$ & 0.0097 & $1.0000(2)$ & 0.0000 & $1.0000(1.5)$ & 0.0000 \\
\hline & G & & & $0.9795(6)$ & 0.0117 & $0.9785(7)$ & 0.0142 & $0.9226(7)$ & 0.0237 & $0.9777(7)$ & 0.0137 & $0.9592(6)$ & 0.0181 \\
\hline \multirow{2}{*}{ All Taggers } & $F$-test & & & 1.3856 & & 0.3499 & & 1.1805 & & 0.6034 & & 1.6362 & \\
\hline & $P$-value & & & 0.2159 & & 0.9103 & & 0.3130 & & 0.7279 & & 0.1326 & \\
\hline \multirow{2}{*}{$\begin{array}{l}\text { Tagger G } \\
\text { Omitted }\end{array}$} & $F$-test & & & 1.5552 & & 0.3728 & & 0.7505 & & 0.4070 & & 1.7774 & \\
\hline & $P$-value & & & 0.1691 & & 0.8676 & & 0.5856 & & 0.8443 & & 0.1138 & \\
\hline
\end{tabular}


Table 3.2. (Continued)

\begin{tabular}{|c|c|c|c|c|c|c|c|c|c|}
\hline \multirow{3}{*}{$\begin{array}{l}\text { Release } \\
\text { Site }\end{array}$} & \multirow[b]{3}{*}{ Tagger } & \multicolumn{6}{|c|}{ Cormack-Jolly-Seber Survival } & & \\
\hline & & \multicolumn{2}{|c|}{ Release 275 to 234} & \multicolumn{2}{|c|}{ Rkm 234 to 153} & \multicolumn{2}{|c|}{ Rkm 153 to 113} & \multicolumn{2}{|c|}{ Rkm 113 to 86} \\
\hline & & Estimate & SE & Estimate & SE & Estimate & SE & Estimate & SE \\
\hline \multirow{7}{*}{$R_{3}$} & A & $0.9807(7)$ & 0.0133 & $0.9669(4)$ & 0.0172 & $0.9834(4)$ & 0.0125 & $0.9764(6)$ & 0.0148 \\
\hline & B & $0.9948(4)$ & 0.0075 & $0.9691(3)$ & 0.0161 & $0.9832(5)$ & 0.0121 & $0.9980(4)$ & 0.0087 \\
\hline & $\mathrm{C}$ & $0.9987(3)$ & 0.0106 & $0.9289(7)$ & 0.0256 & $0.9686(7)$ & 0.0179 & $1.0000(2)$ & 0.0000 \\
\hline & $\mathrm{D}$ & $0.9871(5)$ & 0.0121 & $0.9616(5)$ & 0.0188 & $\begin{array}{l}1.0000 \\
(1.5)\end{array}$ & 0.0000 & $1.0000(2)$ & 0.0000 \\
\hline & $\mathrm{E}$ & $1.0000(1.5)$ & 0.0000 & $1.0000(1)$ & 0.0000 & $\begin{array}{l}1.0000 \\
(1.5)\end{array}$ & 0.0231 & $0.9714(7)$ & 0.0281 \\
\hline & $\mathrm{F}$ & $0.9834(6)$ & 0.0122 & $0.9837(2)$ & 0.0132 & $0.9889(3)$ & 0.0111 & $1.0000(2)$ & 0.0102 \\
\hline & G & $1.0000(1.5)$ & 0.0132 & $0.9368(6)$ & 0.0211 & $0.9753(6)$ & 0.0141 & $0.9844(5)$ & 0.0111 \\
\hline \multirow{2}{*}{ All Taggers } & $F$-test & 0.5817 & & 1.9750 & & 0.6559 & & 0.8239 & \\
\hline & $P$-value & 0.7453 & & 0.0654 & & 0.6854 & & 0.5511 & \\
\hline \multirow{2}{*}{$\begin{array}{l}\text { Tagger G } \\
\text { Omitted }\end{array}$} & $F$-test & 0.6246 & & 1.9621 & & 0.6627 & & 0.8980 & \\
\hline & $P$-value & 0.6810 & & 0.0808 & & 0.6518 & & 0.4812 & \\
\hline
\end{tabular}




\subsubsection{Arrival Distributions}

The estimated probability an acoustic tag was active when fish arrived at a downstream detection array depends on the tag-life curve and the distribution of observed travel times. These probabilities were calculated by integrating the tag survivorship curve (Figure 3.4) over the observed distribution of fish arrival times (i.e., time from tag activation to arrival). The estimated probabilities of tag activation for the various release groups at the different detection arrays always exceeded 0.999 (Table 3.3). The tag-lifeadjusted survival estimates were based on the estimated probabilities of tag activation (Table 3.3).

The last distinct detection array used in the survival analysis was rkm 86 (Figure 3.5). Plots of the arrival distributions of the three release groups (i.e., $V_{1}, R_{2}$, and $R_{3}$ ) to that array indicate the subyearling Chinook salmon (Figure 3.5) should have arrived well before tag failure became problematic. Tag-life adjustments to survival estimates would be incomplete if fish have arrival times beyond the range of observed tag lives.

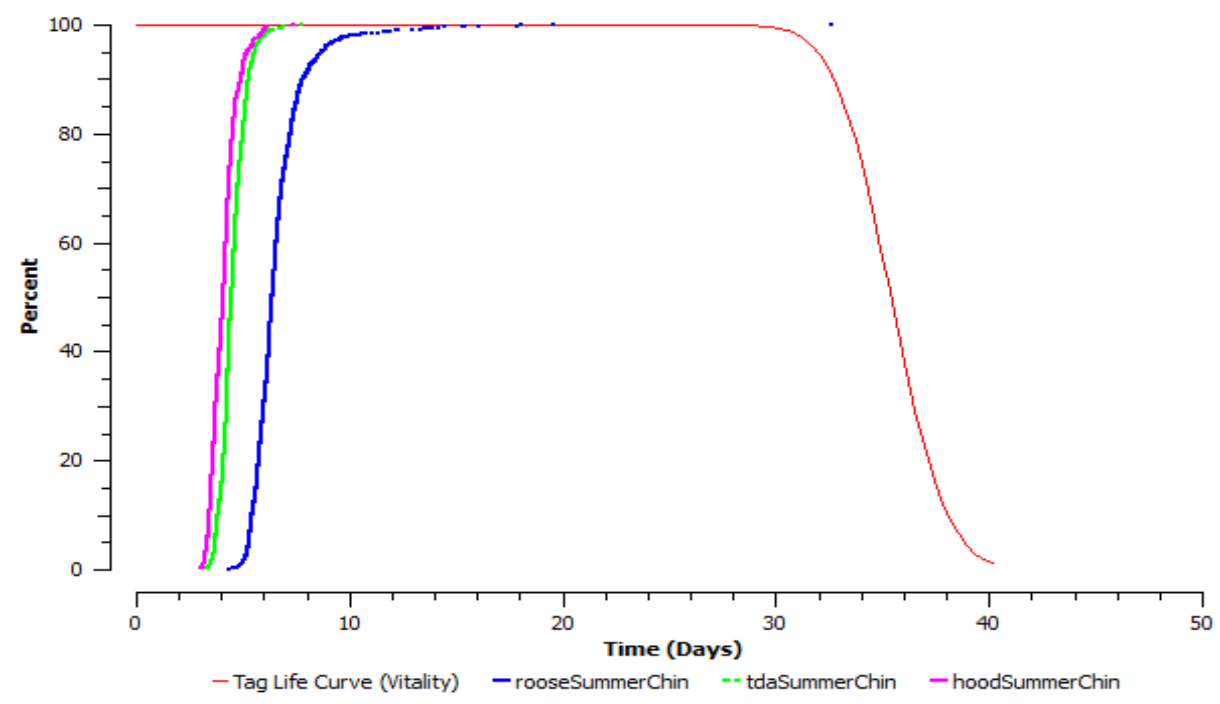

Figure 3.5. Plot of the Fitted Tag-Life Survivorship Curve and the Arrival-Time Distributions of Subyearling Chinook Salmon Smolts for Releases $V_{1}, R_{2}$, and $R_{3}$ at the Acoustic-Detection Array Located at Rkm 86.0 (Figure 2.1)

Table 3.3. Estimated Probabilities $(L)$ of an Acoustic Tag Being Active When a Subyearling Chinook Salmon Smolt Arrived at a Detection Array Used in Estimating Dam Passage Survival at The Dalles Dam in 2010. For the $V_{1}$ release, the $L$ values are the conditional probability a tag is active, given it was active at the time the group was formed at the detection array at rkm 309. (Standard errors are in parentheses.)

\begin{tabular}{ccccccc}
\hline \multirow{2}{*}{$\begin{array}{c}\text { Release } \\
\text { Group }\end{array}$} & D2: Rkm 275 & D3: Rkm 234 & D4: Rkm 153 & D5: Rkm 113 & D6: Rkm 86 & Rkm (49-3) \\
\cline { 3 - 6 }$V_{1}$ & $1.0000(0.000200)$ & $1.0000(0.000432)$ & $1.0000(0.000774)$ & $1.0000(0.000922)$ & $0.9999(0.001027)$ & $0.9999(0.001232)$ \\
$R_{2}$ & -- & $1.0000(0.000863)$ & $1.0000(0.001224)$ & $1.0000(0.001386)$ & $1.0000(0.001495)$ & $1.0000(0.001706)$ \\
$R_{3}$ & -- & $1.0000(0.000707)$ & $1.0000(0.001076)$ & $1.0000(0.001239)$ & $1.0000(0.001360)$ & $1.0000(0.001569)$ \\
\hline
\end{tabular}




\subsubsection{Downstream Mixing}

To help induce downstream mixing of the release groups, the $R_{1}$ release of subyearling Chinook salmon smolts was, on average, $60 \mathrm{~h}$ before the $R_{2}$ release which, in turn, occurred $13 \mathrm{~h}$ before $R_{3}$. Plots of the arrival timing of the various release groups at downstream detection sites indicate reasonable mixing (Figure 3.6). The arrival modes for releases $R_{2}$ and $R_{3}$ were nearly synchronous. The modes for $R_{2}$ and $R_{3}$ were slightly later than the arrival mode for $V_{1}$ but during the majority of the distribution of arrival times for $V_{1}$ (Figure 3.6).
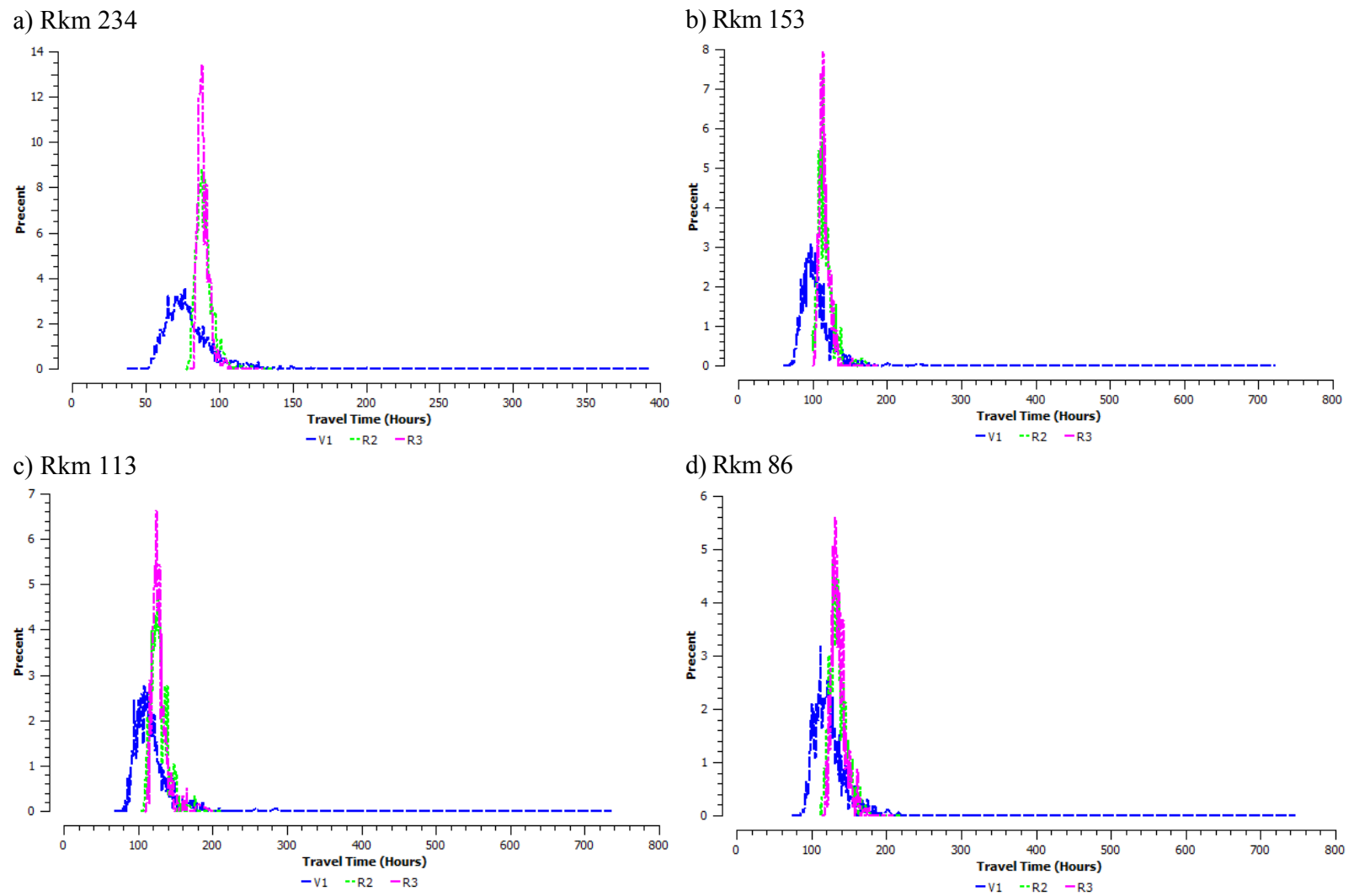

Figure 3.6. Frequency Distribution Plots of Downstream Arriving Timing (expressed as percentages) for Subyearling Chinook Salmon Releases $V_{1}, R_{2}$, and $R_{3}$ at Detection Arrays Located at (a) Rkm 234, (b), Rkm 153, (c) Rkm 113, and (d) Rkm 86. (See Figure 2.1). All times adjusted relative to the release time of $R_{1 . .}$ The distributions averaged over all release groups.

\subsection{Survival and Passage Estimates}

This section contains estimates for dam passage survival, forebay-to-tailrace passage survival, forebay residence time, tailrace egress time, spill passage efficiency, and fish passage efficiency.

\subsubsection{Dam Passage Survival}

The estimates of dam passage survival were based on the virtual/paired-release design using capture history data (Appendix A, Tables A.1 and A.2) and the fitted tag-life curve (Figure 3.4). The estimator included tag-life-adjusted survival estimates for releases $V_{1}, R_{2}$, and $R_{3}$. A total of six detection sites were 
used in the analysis (Figure 2.1, Table 3.4), plus the pooling of detections at arrays rkm $49-\mathrm{rkm} \mathrm{3,} \mathrm{to}$ assure all available information was used in the estimation process. A fully parameterized model with distinct survival and capture probabilities for each release group was used to assure robustness of the estimation procedure.

The estimate of dam passage survival was based on the survival of $V_{1}$ to detection array $D_{1}$ divided by an estimate of reach survival between the tailrace array ( $\mathrm{rkm} 307)$ and $D_{1}$. Using the tag-life-adjusted survival estimates for subyearling Chinook salmon smolts (Table 3.4), dam passage survival at The Dalles Dam was calculated to be

$$
\hat{S}_{\mathrm{TDA}}=\frac{\hat{S}_{1}}{\left(\frac{\hat{S}_{2}}{\hat{S}_{3}}\right)}=\frac{0.9210}{\left(\frac{0.9707}{0.9912}\right)}=\frac{0.9210}{0.9793}=0.9404
$$

with an associated standard error of 0.0091.

Additional analyses indicated this estimate of survival was robust to the number of downstream detection arrays used and whether the downstream survival and detection probabilities were modeled to be homogeneous across reaches or not. The standard error is based on both the multinomial sampling error of the release-recapture process and the sampling error associated with the estimation of the probabilities of tag activation (Table 3.3).

The estimate of dam survival for subyearling Chinook salmon at The Dalles in 2010 achieves the BiOp requirement for $\hat{S}_{\text {Dam }} \geq 0.93$ and the standard error requirement of $\widehat{\mathrm{SE}} \leq 0.015$. 
Table 3.4. Tag-Life-Adjusted Survival Estimates of Reach Survival and Detection Probabilities for Subyearling Chinook Salmon Smolts Used in Estimating Dam Passage Survival at The Dalles Dam in 2010. Parameter estimates based on fully parameterized release-recapture models for each group. Standard errors (SE) based on both the inverse hessian matrix and bootstrapping for key parameters $(\dagger)$ and only the inverse hessian matrix for associated parameters $(*)$.

\section{Survival Probabilities}

\begin{tabular}{|c|c|c|c|c|c|c|c|c|c|c|c|c|}
\hline \multirow{2}{*}{$\begin{array}{c}\text { Release } \\
\text { Group }\end{array}$} & \multicolumn{2}{|c|}{ Rkm 309 to 275} & \multicolumn{2}{|c|}{ Rkm 275 to 234} & \multicolumn{2}{|c|}{ Release to Rkm 234} & \multicolumn{2}{|c|}{$\mathrm{Rkm} 234$ to 153} & \multicolumn{2}{|c|}{ Rkm 153 to 113} & \multicolumn{2}{|c|}{ Rkm 113 to 86.2} \\
\hline & Estimate & $\mathrm{SE} \dagger$ & Estimate & SE* & Estimate & $\mathrm{SE} \dagger$ & Estimate & $\mathrm{SE}^{*}$ & Estimate & SE* & Estimate & $\mathrm{SE}^{*}$ \\
\hline$V_{1}$ & 0.9210 & 0.005492 & 0.9794 & 0.003308 & --- & --- & 0.9332 & 0.005673 & 0.9814 & 0.003322 & 0.9875 & 0.002763 \\
\hline$R_{2}$ & --- & --- & --- & --- & 0.9707 & 0.006393 & 0.9556 & 0.007827 & 0.9904 & 0.004148 & 0.9746 & 0.006189 \\
\hline$R_{3}$ & --- & --- & --- & --- & 0.9912 & 0.004090 & 0.9591 & 0.007577 & 0.9839 & 0.004966 & 0.9930 & 0.003760 \\
\hline
\end{tabular}

\section{Detection Probabilities}

\begin{tabular}{|c|c|c|c|c|c|c|c|c|c|c|c|c|}
\hline \multirow[b]{2}{*}{$\begin{array}{l}\text { Release } \\
\text { Group }\end{array}$} & \multicolumn{2}{|c|}{$D_{1}$} & \multicolumn{2}{|c|}{$D_{2}$} & \multicolumn{2}{|c|}{$D_{3}$} & \multicolumn{2}{|c|}{$D_{4}$} & \multicolumn{2}{|c|}{$D_{5}$} & \multicolumn{2}{|c|}{$\begin{array}{c}\lambda \\
\text { Survival } \times \text { Capture }\end{array}$} \\
\hline & Estimate & $\mathrm{SE}^{*}$ & Estimate & $\mathrm{SE}^{*}$ & Estimate & $\mathrm{SE}^{*}$ & Estimate & $\mathrm{SE}^{*}$ & Estimate & $\mathrm{SE}^{*}$ & Estimate & $\mathrm{SE}^{*}$ \\
\hline$V_{1}$ & 0.9995 & 0.000460 & 0.9463 & 0.005006 & 0.8551 & 0.007936 & 0.9562 & 0.004647 & 0.9349 & 0.005677 & 0.9720 & 0.003875 \\
\hline$R_{2}$ & --- & --- & 0.9271 & 0.009549 & 0.8597 & 0.012820 & 0.9497 & 0.008178 & 0.9507 & 0.008251 & 0.9618 & 0.007343 \\
\hline$R_{3}$ & --- & --- & 0.9130 & 0.010228 & 0.8728 & 0.012190 & 0.9541 & 0.007697 & 0.9352 & 0.009238 & 0.9568 & 0.007720 \\
\hline
\end{tabular}

* Standard error is based on the inverse Hessian.

$\uparrow$ Standard error is based on bootstrapping.

\subsubsection{Forebay-to-Tailrace Passage Survival}

The estimate of forebay-to-tailrace passage survival was calculated analogously to that of dam passage survival except the virtual -release group (V1) was composed of fish known to have arrived at the forebay (i.e., detection array rkm 311, Figure 2.1) rather than at the dam face. Although the capture history data for $V_{1}$ changed (Appendix A, Table A.1), the same capture-history data were used for releases $R_{2}$ and $R_{3}$ (Appendix A, Table A.2). Using the same statistical model as was used in estimating dam passage survival, forebay-to-tailrace survival for yearling Chinook salmon was estimated to be

$$
\hat{S}_{\text {Forebay-to-tailrace }}=0.9356(\widehat{\mathrm{SE}}=0.0092) .
$$

As might be expected, the forebay-to-tailrace survival estimate was slightly lower than the respective estimate of dam passage survival due to the additional travel distance above the dam. The Fish Accords do not have compliance standards for either the forebay-to-tailrace survival estimate or its standard error. Nevertheless, standard errors for the estimates of dam passage survival and forebay-to-tailrace should be similar because of the very similar sample sizes used in both calculations. 


\subsubsection{Forebay Residence Time}

The forebay residence times were based on the times from the first detection within $100 \mathrm{~m}$ of the dam face to the last detection at the double array in front of The Dalles Dam. The timing of the first detection within $100 \mathrm{~m}$ of the dam was based on 3D tracking of the acoustic-tagged fish and interpretation of the time when the fish first crossed the 100-m distance threshold.

Distribution of forebay residence times ranged from $0.02 \mathrm{~h}$ to $169.2 \mathrm{~h}$ for subyearling Chinook salmon (Figure 3.7). Mean residence time for subyearling Chinook salmon smolts was estimated to be $\bar{t}$ $=0.72 \mathrm{~h}(\widehat{\mathrm{SE}}=0.28, n=1,584)$. The median was $0.25 \mathrm{~h}$.

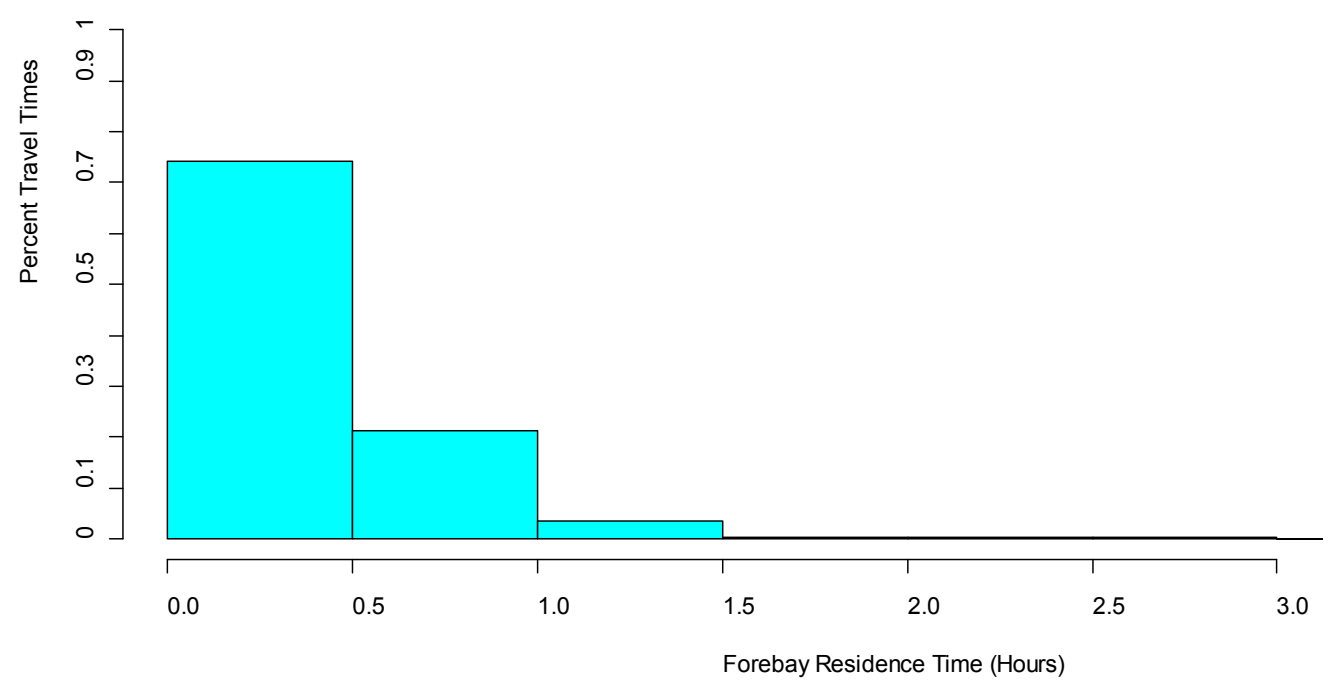

Figure 3.7. Distribution of Forebay Residence Times for Subyearling Chinook Salmon Smolts at The Dalles Dam, 2010

\subsubsection{Tailrace Egress Time}

The tailrace egress time was calculated based on the time from the last detection of fish at the double array at the face of The Dalles Dam to the first detection at the BRZ tailrace array. The range of tailrace egress times for subyearling Chinook salmon was $0.098 \mathrm{~h}$ to $298.78 \mathrm{~h}$ (Figure 3.8). Mean tailrace egress time for subyearling Chinook salmon smolts was estimated to be $\bar{t}=1.42(\widehat{\mathrm{SE}}=0.28, n=2,054)$. Like forebay residence time, the median was $0.25 \mathrm{~h}$. 


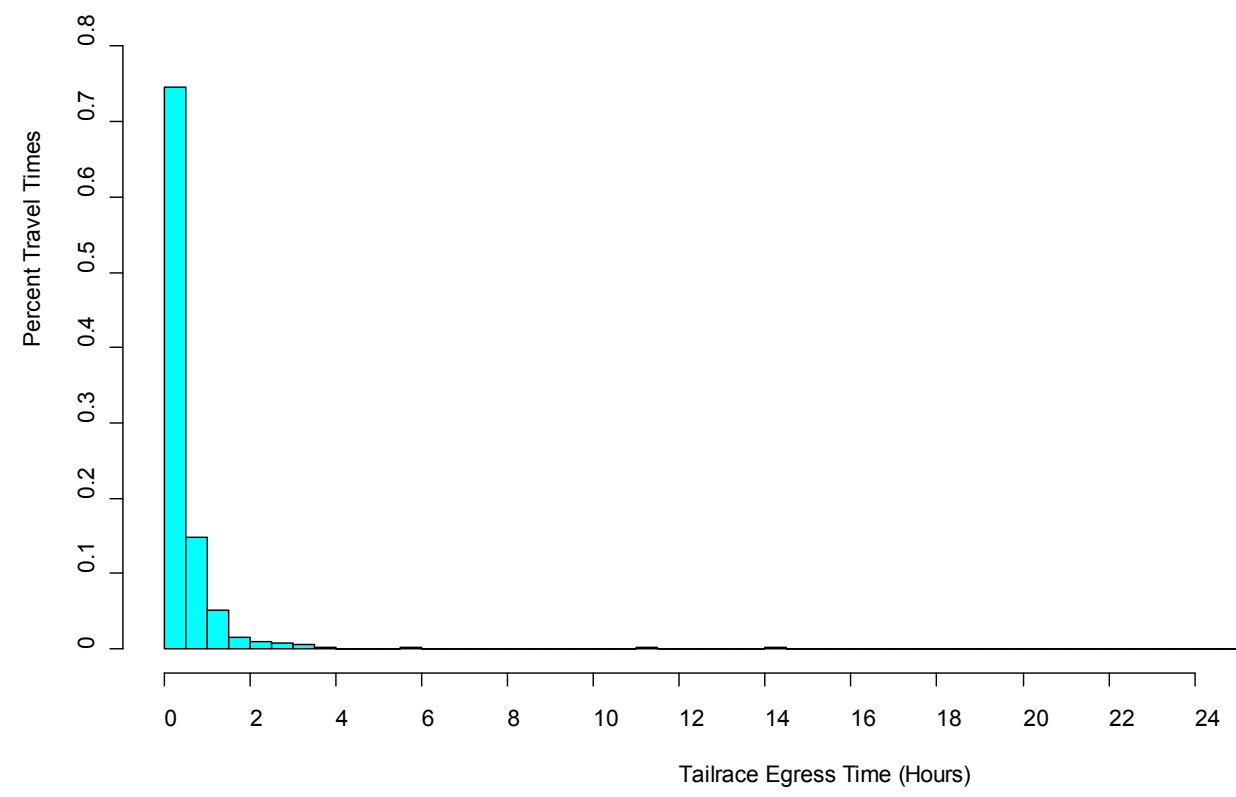

Figure 3.8. Distribution of Tailrace Egress Times for Subyearling Chinook Salmon Smolts at The Dalles Dam, 2010

\subsubsection{Spill Passage Efficiency}

Spill passage efficiency (SPE) is the fraction of the fish that passed through a hydropower project by the spillway. (In the Fish Accords, the definition of SPE also included sluice passage. This metric is presented below as Fish Passage Efficiency.) The double-detection array at the face of The Dalles Dam was used to identify and track fish as they entered the dam. Using the observed counts and assuming detection efficiency was $100 \%$, the number of fish entering the spillway and powerhouse were used to estimate SPE using a binomial sampling model. For subyearling Chinook salmon smolts at The Dalles Dam in 2010, the proportion of fish that went through the spillway is estimated to be

$$
\widehat{\mathrm{SPE}}=0.7122(\widehat{\mathrm{SE}}=0.0092, n=2415)
$$

\subsubsection{Fish Passage Efficiency}

Fish passage efficiency (FPE), called spill passage efficiency in the Fish Accords, is the fraction of the fish that passed through a hydropower project by the spillway and the sluiceway. As with spill passage efficiency, the double-detection array at the face of The Dalles Dam was used to identify and track fish as they entered the dam. Using the observed counts and assuming detection efficiency was $100 \%$, the number of fish entering the spillway and powerhouse were used to estimate FPE using a binomial sampling model. For subyearling Chinook salmon smolts at The Dalles Dam in 2010, fish passage efficiency is estimated to be

$$
\widehat{\mathrm{FPE}}=0.8298(\widehat{\mathrm{SE}}=0.0076, n=2415)
$$




\subsection{Discussion}

\subsection{Historical Context}

Historically, telemetry studies have been used to estimate survival rates for subyearling Chinook salmon passing The Dalles Dam. For radio-tag studies conducted during 2002, 2004, and 2005 (Counihan et al. 2006a, 2006b, 2006c), survival estimates were generated using the route-specific survival model for radio-tagged fish released by boat in the tailraces of John Day Dam (treatment) and The Dalles Dam (control). As summarized by Johnson et al. (2007:7.3), the mean dam survival rate for subyearling Chinook salmon over the three study-years was 0.883 .

During the subyearling Chinook salmon migration in summer 2006, an acoustic-tag study was used to estimate passage survival at The Dalles Dam (Ploskey et al. 2007). The estimation process involved releases from the John Day and The Dalles Dam tailraces along with downstream detections at The Dalles Dam primary (rkm 275), The Dalles secondary ( $\mathrm{rkm} 234$ ), and Bonneville Dam primary (rkm 153) arrays. At The Dalles Dam, project passage survival was estimated to be 0.9404 ( $\widehat{\mathrm{SE}}=0.0091$ ) for subyearling Chinook salmon.

During 2008 and 2009, Weiland et al. (2009 and 2010, respectively) performed acoustic-tag studies at John Day Dam that included releases and downstream detection arrays allowing estimation of survival between forebay arrays at The Dalles and Bonneville dams. Specifically, tagged fish were released near Arlington, Oregon (rkm 390) and in the John Day Dam tailrace (rkm 343.4), and regrouped on The Dalles Dam forebay entrance array to create virtual releases for estimating single-release dam-passage survival rates for The Dalles Dam. Tag-life-corrected survival rates from $2 \mathrm{~km}$ upstream of The Dalles Dam to the Bonneville Dam forebay, estimated for subyearling Chinook salmon using a single-release model, were as follows $( \pm 95 \% \mathrm{CI})$ :

\begin{tabular}{cc}
\hline Year & Subyearling Chinook Salmon \\
\hline 2008 & $0.931 \pm 0.013$ \\
2009 & $0.789 \pm 0.051$ \\
\hline
\end{tabular}

Thus, the 2010 dam passage survival of 0.9404 for subyearling Chinook salmon is higher than recent estimates of passage survival estimates from 2008 and 2009 for The Dalles Dam.

\subsection{Statistical Performance}

The BiOp requires estimates of dam passage survival with standard errors $\leq 0.015$. The numbers of tagged fish released (Table 2.1) and the detection probabilities at the downstream hydrophone arrays (Table 3.5) in summer 2010 were found to be adequate to achieve this precision requirement. The estimated standard error for subyearling Chinook salmon was $<0.01$. Therefore, the number of tagged fish released for the survival studies in future years should be comparable to those used in 2010 to help assure precision requirements will be achieved. Should levels of hydrophone deployment change, the number of fish tagged may need to be reassessed. 


\subsection{Model Assumptions}

The summer subyearling Chinook salmon study at The Dalles Dam is the second full-scale application of the virtual/paired-release design of Skalski et al. (2010) in the FCRPS. The first study was the spring yearling Chinook salmon and steelhead study at the Dalles Dam (Pacific Northwest National Laboratory and University of Washington 2010). The virtual-paired release design worked as conceived. The virtual release group $\left(V_{1}\right)$ estimated smolt passage survival from the dam face to a downriver detection array at $\mathrm{rkm} 275$. This array at $\mathrm{rkm} 275$ was selected because it was sufficiently downriver to assure any fish that died during dam passage with a still active tag would not be detected on downstream arrays. A separate release of 21 dead fish with active tags at The Dalles Dam spillway in 2010 resulted in no downstream detections at rkm 275. To account for the extra mortality between the tailrace and the detection array at rkm 275, a paired release using groups $R_{2}$ and $R_{3}$ was used to estimate reach survival in the upper part of the Bonneville reservoir. The quotient of the survival estimates from the virtual release $\left(V_{1}\right)$ and paired release $\left(R_{2}\right.$ and $\left.R_{3}\right)$ was the basis for the estimates of dam passage survival in this report.

Graphs of arrival timing (Figure 3.6) indicate the release timing of the different tag groups was appropriate for adequate downstream mixing of fish. Travel times were also sufficiently short relative to tag life to adequately adjust the release-recapture data for tag failure (Figure 3.5). In all cases, the probability that an acoustic tag was active at a downstream detection location was $>0.999$ (Table 3.3). In other words, for this summer investigation, very little tag-life correction was needed to produce unbiased survival estimates.

The estimate of dam passage survival of $\hat{S}_{\mathrm{TDA}}=0.9404(\widehat{\mathrm{SE}}=0.0091)$ for subyearling Chinook salmon smolts was found to be robust to the number of downstream detection arrays used in the analysis and whether the release-recapture models were reparameterized for downstream homogeneity of survival and detection probabilities. Using as few as three downstream detection arrays (plus arrays rkm 3--153 pooled) produced the same survival results as those reported. Using even fewer downstream detection arrays still produced estimates of dam passage survival $>0.93$. We are therefore confident that the 2010 subyearling Chinook salmon survival study at The Dalles Dam met the BiOp survival standard. 


\subsection{References}

3 Treaty Tribes-Action Agencies. 2008. Memorandum of Agreement Among the Umatilla, Warm Springs and Yakama Tribes, Bonneville Power Administration, U.S. Army Corps of Engineers, nd U.S. Bureau of Reclamation, Portland, Oregon, April 4, 2008. Available at http://www.salmonrecovery.gov/ColumbiaBasinFishAccords.aspx.

Burnham, KP, DR Anderson, GC White, C Brownie, and KH Pollock. 1987. "Design and analysis methods for fish survival experiments based on release-recapture." American Fisheries Society Monograph 5. Bethesda, Maryland.

Counihan, TD, G. Holmberg, CE Walker, and JM Hardiman. 2006a. Survival estimates of migrant juvenile salmonids through The Dalles Dam using radiotelemetry, 2002. Final report of research prepared for the U.S. Army Corps of Engineers, Portland, Oregon by the US Geological Survey, Cook, Washington.

Counihan, TD, AL Puls, CE Walker, JM Hardiman, and GS Holmberg. 2006b. Survival estimates of migrant juvenile salmonids through The Dalles Dam using radiotelemetry, 2004. Final report of research prepared for the U.S. Army Corps of Engineers, Portland, Oregon by the US Geological Survey, Cook, Washington.

Counihan, TD, AL Puls, CE Walker, JM Hardiman, and GS Holmberg. 2006c. Survival estimates of migrant juvenile salmonids through The Dalles Dam using radiotelemetry, 2005. Final report of research prepared for the U.S. Army Corps of Engineers, Portland, Oregon by the US Geological Survey, Cook, Washington.

Johnson, GE, JW Beeman, IN Duran, and AL Puls. 2007. Synthesis of juvenile salmonid passage studies at The Dalles Dam, Volume II, 2001-2005. PNNL-16443, final report submitted to the U.S. Army Corps of Engineers, Portland District, Portland, Oregon, by Pacific Northwest National Laboratory, Richland, Washington.

Li, T, and JJ Anderson. 2009. "The vitality model: A way to understand population survival and demographic heterogeneity." Theoretical Population Biology 76:118-131.

Martinson, R, G Kovalchuk, and D Ballinger. 2006. Monitoring of downstream salmon and steelhead at federal hydroelectric facilities. 2005-2006 Annual Report, Project No. 198712700, BPA Report DOE/BP-00022085-2, Portland, Oregon.

NOAA (National Atmospheric and Oceanic Administration) Fisheries. 2008. Biological OpinionConsultation on Remand for Operation of the Federal Columbia River Power System, 11 Bureau of Reclamation Projects in the Columbia Basin and ESA Section 10(a)(1)(A) Permit for Juvenile Fish Transportation Program. National Marine Fisheries Service (NOAA Fisheries) - Northwest Region, Seattle, Washington. Available at http://www.salmonrecovery.gov/.

Pacific Northwest National Laboratory and University of Washington. 2010. Compliance monitoring of juvenile yearling Chinook salmon and steelhead survival and passage at The Dalles Dam, Spring 2010. PNNL-19919, draft report submitted to the U.S. Army Corps of Engineers, Portland District, Portland, Oregon, by Pacific Northwest National Laboratory, Richland, Washington. 
Ploskey, GR, MA Weiland, JS Hughes, SR Zimmerman, RE Durham, ES Fischer, J Kim, RL Townsend, JR Skalski, and RL McComas. 2007. Acoustic Telemetry Studies of Juvenile Chinook Salmon Survival at the Lower Columbia Projects in 2006. PNNL-16560, final report prepared for U.S. Army Corps of Engineers District, Portland, Oregon, by Pacific Northwest National Laboratory, Richland, Washington.

Seber, GAF. 1982. The Estimation of Animal Abundance. MacMillan, New York.

Skalski, JR, RL Townsend, TW Steig, and S Hemstrom. 2010. "Comparison of two alternative approaches for estimating dam passage survival using acoustic-tagged sockeye salmon smolts." North American Journal of Fisheries Management 30:831-839.

Townsend, RL, JR Skalski, P Dillingham, and TW Steig. 2006. "Correcting bias in survival estimation resulting from tag failure in acoustic and radiotelemetry studies." Journal of Agricultural Biology and Environmental Statistics 11(2):183-196.

Weiland, MA, GR Ploskey, JS Hughes, Z Deng, T Fu, TJ Monter, GE Johnson, F Khan, MC Wilberding, AW Cushing, SA Zimmerman, DM Faber, RE Durham, RL Townsend, JR Skalski, J Kim, ES Fischer, and MM Meyer. 2009. Acoustic Telemetry Evaluation of Juvenile Salmonid Passage and Survival at John Day Dam with Emphasis on the Prototype Surface Flow Outlet, 2008. PNNL18890, Pacific Northwest National Laboratory, Richland, WA.

Weiland, MA and eighteen co-authors. 2010. Acoustic telemetry evaluation of juvenile salmonid passage and survival proportions at John Day Dam, 2009. PNNL-19422, draft final report submitted to the U.S. Army Corps of Engineers, Portland District, Portland, Oregon, by Pacific Northwest National Laboratory, Richland, Washington. 
Appendix A

Capture History Data 

Table A.1. Capture Histories at Sites $D_{1}-D_{6}$ (Figure 2.1) for Release Group $V_{1}$ for Subyearling Chinook Salmon Used in Estimating Dam Passage Survival and BRZ-to-BRZ Survival. A "1" Denotes Detection, "0" Denotes Nondetection, and "2" Denotes Detection and Censoring Due to Removal.

\begin{tabular}{|c|c|c|}
\hline \multirow[b]{2}{*}{ Capture History } & \multicolumn{2}{|c|}{$V_{1}$} \\
\hline & $\begin{array}{c}\text { Dam Passage } \\
\text { Survival }\end{array}$ & $\begin{array}{c}\text { BRZ-to-BRZ } \\
\text { Survival }\end{array}$ \\
\hline $111111:$ & 1365 & 1361 \\
\hline 0111111 : & 0 & 0 \\
\hline 101111 : & 86 & 86 \\
\hline $\begin{array}{llllll:}0 & 0 & 1 & 1 & 1 & 1\end{array}$ & 0 & 0 \\
\hline 110111 : & 226 & 226 \\
\hline 010111 : & 0 & 0 \\
\hline 100111 : & 10 & 10 \\
\hline 000111 : & 0 & 0 \\
\hline 111011 : & 66 & 66 \\
\hline 0111011 : & 0 & 0 \\
\hline 101011 : & 2 & 2 \\
\hline 001011 : & 0 & 0 \\
\hline 110011 : & 11 & 11 \\
\hline 010011 : & 0 & 0 \\
\hline 100011 : & 0 & 0 \\
\hline 0000011 : & 0 & 0 \\
\hline $111101:$ & 83 & 83 \\
\hline $0111101:$ & 1 & 1 \\
\hline 101101 : & 4 & 4 \\
\hline $001101:$ & 0 & 0 \\
\hline $110101:$ & 30 & 30 \\
\hline $010101:$ & 0 & 0 \\
\hline $100101:$ & 0 & 0 \\
\hline 00010 1: & 0 & 0 \\
\hline $111001:$ & 5 & 5 \\
\hline $0111001:$ & 0 & 0 \\
\hline $101001:$ & 0 & 0 \\
\hline $001001:$ & 0 & 0 \\
\hline $110001:$ & 0 & 0 \\
\hline $0100001:$ & 0 & 0 \\
\hline $100001:$ & 0 & 0 \\
\hline $\begin{array}{llllll:}0 & 0 & 0 & 0 & 0 & 1:\end{array}$ & 0 & 0 \\
\hline 111120 : & 0 & 0 \\
\hline 0111120 : & 0 & 0 \\
\hline 101120 : & 0 & 0 \\
\hline 0011120 : & 0 & 0 \\
\hline 110120 : & 0 & 0 \\
\hline 010120 : & 0 & 0 \\
\hline $100120:$ & 0 & 0 \\
\hline 000120 : & 0 & 0 \\
\hline 111020 : & 0 & 0 \\
\hline 0111020 : & 0 & 0 \\
\hline 10101020 : & 0 & 0 \\
\hline
\end{tabular}




\begin{tabular}{|c|c|c|}
\hline \multirow[b]{2}{*}{ Capture History } & \multicolumn{2}{|c|}{$V_{1}$} \\
\hline & $\begin{array}{c}\text { Dam Passage } \\
\text { Survival }\end{array}$ & $\begin{array}{l}\text { BRZ-to-BRZ } \\
\text { Survival }\end{array}$ \\
\hline $\begin{array}{lllllll}0 & 0 & 1 & 0 & 2 & 0:\end{array}$ & 0 & 0 \\
\hline 110020 : & 0 & 0 \\
\hline $\begin{array}{llllll:}0 & 1 & 0 & 0 & 2 & 0 \text { : }\end{array}$ & 0 & 0 \\
\hline $\begin{array}{llllll:}1 & 0 & 0 & 0 & 2 & 0:\end{array}$ & 0 & 0 \\
\hline $\begin{array}{llllll:}0 & 0 & 0 & 0 & 2 & 0:\end{array}$ & 0 & 0 \\
\hline 111110 : & 41 & 41 \\
\hline 01111110 : & 0 & 0 \\
\hline 101110 : & 3 & 3 \\
\hline 0011110 : & 0 & 0 \\
\hline 110110 : & 6 & 6 \\
\hline 0101110 : & 0 & 0 \\
\hline 100110 : & 0 & 0 \\
\hline 0000110 : & 0 & 0 \\
\hline 111010 : & 1 & 1 \\
\hline 0111010 : & 0 & 0 \\
\hline 101010 : & 0 & 0 \\
\hline 0010010 : & 0 & 0 \\
\hline 110010 : & 0 & 0 \\
\hline $0100010:$ & 0 & 0 \\
\hline 100010 : & 0 & 0 \\
\hline 0000010 : & 0 & 0 \\
\hline 111200 : & 0 & 0 \\
\hline 011200 : & 0 & 0 \\
\hline 101200 : & 0 & 0 \\
\hline 001200 : & 0 & 0 \\
\hline 110200 : & 0 & 0 \\
\hline 010200 : & 0 & 0 \\
\hline 100200 : & 0 & 0 \\
\hline 0000200 : & 0 & 0 \\
\hline 111100 : & 22 & 22 \\
\hline 0111100 : & 0 & 0 \\
\hline 101100 : & 3 & 3 \\
\hline 001100 : & 0 & 0 \\
\hline 110100 : & 2 & 2 \\
\hline $010100:$ & 0 & 0 \\
\hline 100100 : & 0 & 0 \\
\hline 0000100 : & 0 & 0 \\
\hline 112000 : & 0 & 0 \\
\hline 012000 : & 0 & 0 \\
\hline 102000 : & 0 & 0 \\
\hline 002000 : & 0 & 0 \\
\hline 111000 : & 32 & 31 \\
\hline 0111000 : & 0 & 0 \\
\hline 101000 : & 1 & 1 \\
\hline 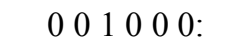 & 0 & 0 \\
\hline 120000 : & 31 & 31 \\
\hline 020000 : & 0 & 0 \\
\hline 110000 : & 141 & 141 \\
\hline 010000 : & 0 & 0 \\
\hline
\end{tabular}




\begin{tabular}{|c|c|c|}
\hline \multirow[b]{2}{*}{ Capture History } & \multicolumn{2}{|c|}{$V_{1}$} \\
\hline & $\begin{array}{c}\text { Dam Passage } \\
\text { Survival }\end{array}$ & $\begin{array}{c}\text { BRZ-to-BRZ } \\
\text { Survival }\end{array}$ \\
\hline $20000000:$ & 0 & 0 \\
\hline $\begin{array}{llllll:}1 & 0 & 0 & 0 & 0 & 0:\end{array}$ & 54 & 54 \\
\hline $\begin{array}{llllll:}0 & 0 & 0 & 0 & 0 & 0:\end{array}$ & 191 & 203 \\
\hline Total & 2,417 & 2,424 \\
\hline
\end{tabular}

Table A.2. Capture Histories at Sites $D_{1}-D_{6}$ (Figure 2.1) for Release Groups $R_{2}$, and $R_{3}$ for Subyearling Chinook Salmon Used in Estimating Dam Passage Survival. A "1" Denotes Detection, "0" Denotes Nondetection, and "2" Denotes Detection and Censoring Due to Removal.

\begin{tabular}{|c|c|c|}
\hline \multirow[b]{2}{*}{ Capture History } & \multicolumn{2}{|c|}{ Dam Passage Survival } \\
\hline & $R_{2}$ & $R_{3}$ \\
\hline $11111:$ & 493 & 505 \\
\hline 0011111 : & 38 & 47 \\
\hline 10111 : & 86 & 71 \\
\hline 000111 : & 6 & 9 \\
\hline 11011 : & 24 & 25 \\
\hline 01011 : & 4 & 2 \\
\hline 10011 : & 4 & 4 \\
\hline $\begin{array}{lllll:}0 & 0 & 0 & 1 & 1 \text { : }\end{array}$ & 0 & 1 \\
\hline $11101:$ & 28 & 37 \\
\hline $011101:$ & 0 & 2 \\
\hline $10101:$ & 5 & 4 \\
\hline $00101:$ & 0 & 2 \\
\hline $11001:$ & 1 & 1 \\
\hline $0 \begin{array}{lllll:}0 & 1 & 0 & 0 & 1:\end{array}$ & 0 & 0 \\
\hline $100001:$ & 0 & 0 \\
\hline $\begin{array}{lllll:}0 & 0 & 0 & 0 & 1:\end{array}$ & 0 & 0 \\
\hline $11120:$ & 0 & 0 \\
\hline 011120 : & 0 & 0 \\
\hline 10120 : & 0 & 0 \\
\hline 00120 : & 0 & 0 \\
\hline $11020:$ & 0 & 0 \\
\hline 01020 : & 0 & 0 \\
\hline 10020 : & 0 & 0 \\
\hline $\begin{array}{lllll}0 & 0 & 0 & 2 & 0 \text { : }\end{array}$ & 0 & 0 \\
\hline 11110 : & 20 & 26 \\
\hline 011110 : & 2 & 1 \\
\hline 10110 : & 1 & 2 \\
\hline 00110 : & 0 & 0 \\
\hline 11010 : & 3 & 0 \\
\hline 01010 : & 0 & 0 \\
\hline 10010 : & 0 & 0 \\
\hline 000010 : & 0 & 1 \\
\hline $11200:$ & 0 & 0 \\
\hline
\end{tabular}




\begin{tabular}{|c|c|c|}
\hline 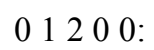 & 0 & 0 \\
\hline 10200 : & 0 & 0 \\
\hline $00200:$ & 0 & 0 \\
\hline $11100:$ & 16 & 5 \\
\hline 011100 : & 2 & 1 \\
\hline 10100 : & 0 & 1 \\
\hline $\begin{array}{lllll:}0 & 0 & 1 & 0 & 0 \text { : }\end{array}$ & 1 & 0 \\
\hline 12000 : & 0 & 0 \\
\hline 02000 : & 0 & 0 \\
\hline $11000:$ & 6 & 11 \\
\hline $\begin{array}{lllll:}0 & 1 & 0 & 0 & 0:\end{array}$ & 1 & 0 \\
\hline $200000:$ & 0 & 1 \\
\hline $\begin{array}{lllll:}1 & 0 & 0 & 0 & 0\end{array}$ & 33 & 31 \\
\hline $\begin{array}{lllll:}0 & 0 & 0 & 0 & 0:\end{array}$ & 26 & 10 \\
\hline Total & 800 & 800 \\
\hline
\end{tabular}




\section{Distribution}

PDF

Copies

\section{External Distribution}

Brad Eppard

USACE Portland District

P.O. Box 2946

Portland, OR 97204

Mike Langeslay

USACE Portland District

P.O. Box 2946

Portland, OR 97204.

John Skalski

University of Washington

$13254^{\text {th }}$ Avenue

Seattle, WA 98101
PDF

Copies

\section{Local Distribution}

Pacific Northwest National Laboratory

Tom Carlson

Gary Johnson

Gene Ploskey

Steve Schlahta

Mark Weiland
BPO

BPO

NBON

$\mathrm{RCH}$

NBON

Distr.1 




\section{IIIIIII}

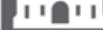

US Army Corps

of Engineers

Prepared for the U.S. Army Corps of Engineers, Portland District, under a Government Order with the U.S. Department of Energy Contract DE-AC05-76RL01830

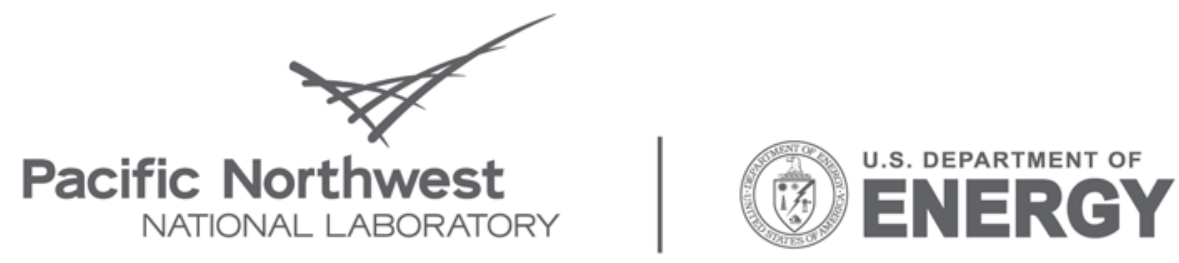

Proudly Operated by Battelle Since 1965

902 Battelle Boulevard

P.O. Box 999

Richland, WA 99352

1-888-375-PNNL (7665)

www.pnl.gov 